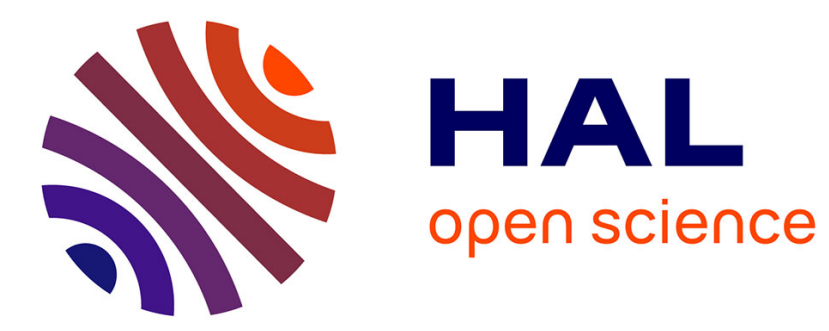

\title{
New insights into the systematics of Parasitiformes (Acarina) with new species from South America
}

\author{
W. Karg, A. Schorlemmer
}

\section{To cite this version:}

W. Karg, A. Schorlemmer. New insights into the systematics of Parasitiformes (Acarina) with new species from South America. Acarologia, 2011, 51 (1), pp.3-29. 10.1051/acarologia/20111995 . hal01599920

\section{HAL Id: hal-01599920 \\ https://hal.science/hal-01599920}

Submitted on 2 Oct 2017

HAL is a multi-disciplinary open access archive for the deposit and dissemination of scientific research documents, whether they are published or not. The documents may come from teaching and research institutions in France or abroad, or from public or private research centers.
L'archive ouverte pluridisciplinaire HAL, est destinée au dépôt et à la diffusion de documents scientifiques de niveau recherche, publiés ou non, émanant des établissements d'enseignement et de recherche français ou étrangers, des laboratoires publics ou privés.

\section{(ㅇ)(1) $\$$}

Distributed under a Creative Commons Attribution - NonCommercial - NoDerivatives $\mid 4.0$ 


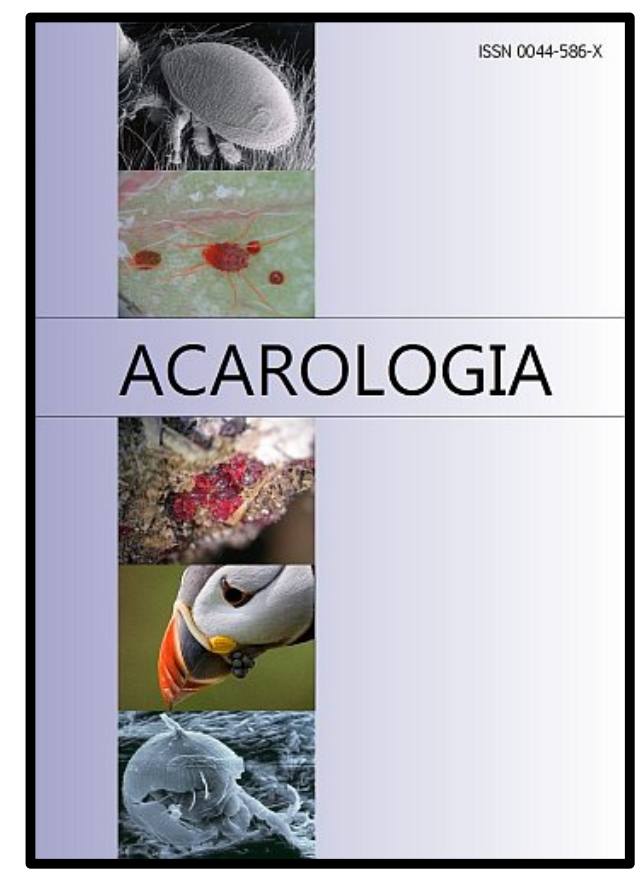

\section{ACAROLOGIA}

A quarterly journal of acarology, since 1959

Publishing on all aspects of the Acari

All information:

http://www1.montpellier.inra.fr/CBGP/acarologia/ acarologia@supagro.inra.fr

\section{OPEN ACCESS}

\section{Acarologia is proudly non-profit, with no page charges and free open access}

Please help us maintain this system by encouraging your institutes to subscribe to the print version of the journal and by sending us your high quality research on the Acari.

Subscriptions: Year 2017 (Volume 57): $380 €$ http://www1.montpellier.inra.fr/CBGP/acarologia/subscribe.php

Previous volumes (2010-2015): $250 € /$ year (4 issues)

Acarologia, CBGP, CS 30016, 34988 MONTFERRIER-sur-LEZ Cedex, France

The digitalization of Acarologia papers prior to 2000 was supported by Agropolis Fondation under the reference ID 1500-024 through the « Investissements d'avenir » programme

(Labex Agro: ANR-10-LABX-0001-01)
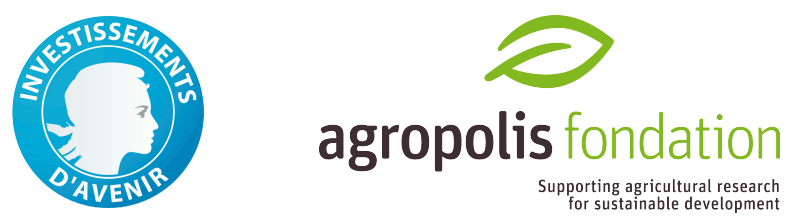

Acarologia is under free license and distributed under the terms of the

Creative Commons-BY-NC-ND which permits unrestricted non-commercial use, distribution, and reproduction in any medium, provided the original author and source are credited. 


\title{
NEW INSIGHTS INTO THE SYSTEMATICS OF PARASITIFORMES (ACARINA) WITH NEW SPECIES FROM SOUTH AMERICA
}

\author{
Wolfgang KARG ${ }^{1}$ and Anita SCHORLEMMER ${ }^{2}$ \\ (Received 22 November 2010; accepted 16 February 2011; published online 30 March 2011) \\ 1 Hohe Kiefer 152, 14532 Kleinmachnow, Germany \\ ${ }^{2}$ Dep. of Molec. Biosciences $\mathcal{E}$ Bioengineering and Dep. of Medicine, University of Hawaii, Ilalo St 651, Honolulu HI 96813, U.S.A. \\ schorlem@hawaii.edu
}

\begin{abstract}
The present study has been initiated by new species from South America and the deviating classification of sub-groups by several authors. We assume a division of the Parasitiformes into three main groups: (1) - Antennophorina Berlese, 1892 s. lat., (2) - Margotrichina Karg et Schorlemmer, 2008, (3) - Gamasina Leach, 1815. Here, we analyse these groups step by step. Cladograms that are based on autapomorphies and synapomorphies visualize relationships between subgroups. (1) - The Antennophorina are divided into the Sejides Berlese and the Trigynaspida Camin et Gorirossi including the Celaenopsoidea Berlese, Cercomegistoidea Trägårdh, Fedrizzioidea Trägårdh, Megisthanoidea Berlese and Trigynaspidoidea Camin et Gorirossi. Two new species belong to the Cercomegistoidea and the Fedrizzioidea. A new genus of the Fedrizziidae is erected: Holostethus n. gen. (2) - Larval-systematic investigations and comparisons of the chaetotaxy of extremities lead to two novel findings. First, the group of the Microgyniina belongs to the Margotrichina. Second, the Thinozerconina have to be separated from the Uropodina group. Hence, the Margotrichina now comprise the four subgroups Microgyniina, Thinozerconina, Uropodina and Ixodides. (3) - The state of art regarding the Gamasina is briefly outlined. We describe two new species of Gamasiphoides - family Gamasiphidae and generate a key for new and known species of the genus.
\end{abstract}

KEYWORDS - classification; revisions; subgroups; diagnoses; cladograms; relationship; phylogenetic working methods; aut- and syn- apomorphies; new genus; new species; key to known and new species

\section{INTRODUCTION}

New species from South America have initiated the present study. These so far unknown species belong to mite groups of the Parasitiformes that have not been studied intensively as for example the Cercomegistoidea, Fedrizzioidea and Gamasiphidae. During our investigations we revealed further groups for which the relationship degree has not been clearly established, as for example for the Microgyniina or the Celaenopsoidea. They are cur- rently assigned to different main groups by several authors.

Our objective is to analyse characteristics and establish cladograms based on autapomorphies and synapomorphies. We already generated a cladogram for the Parasitiformes main groups Antennophorina, Margotrichina and Gamasina (Figure 1), based on synapomorphies (Karg \& Schorlemmer 2008). The subgroup of Uropodina was divided into 3 superfamilies by Karg (1986, 1989): Uropodoidea, Polyaspidoidea and Thinoz- 


\section{Parasitiformes}

Antennophorina

Margotrichina

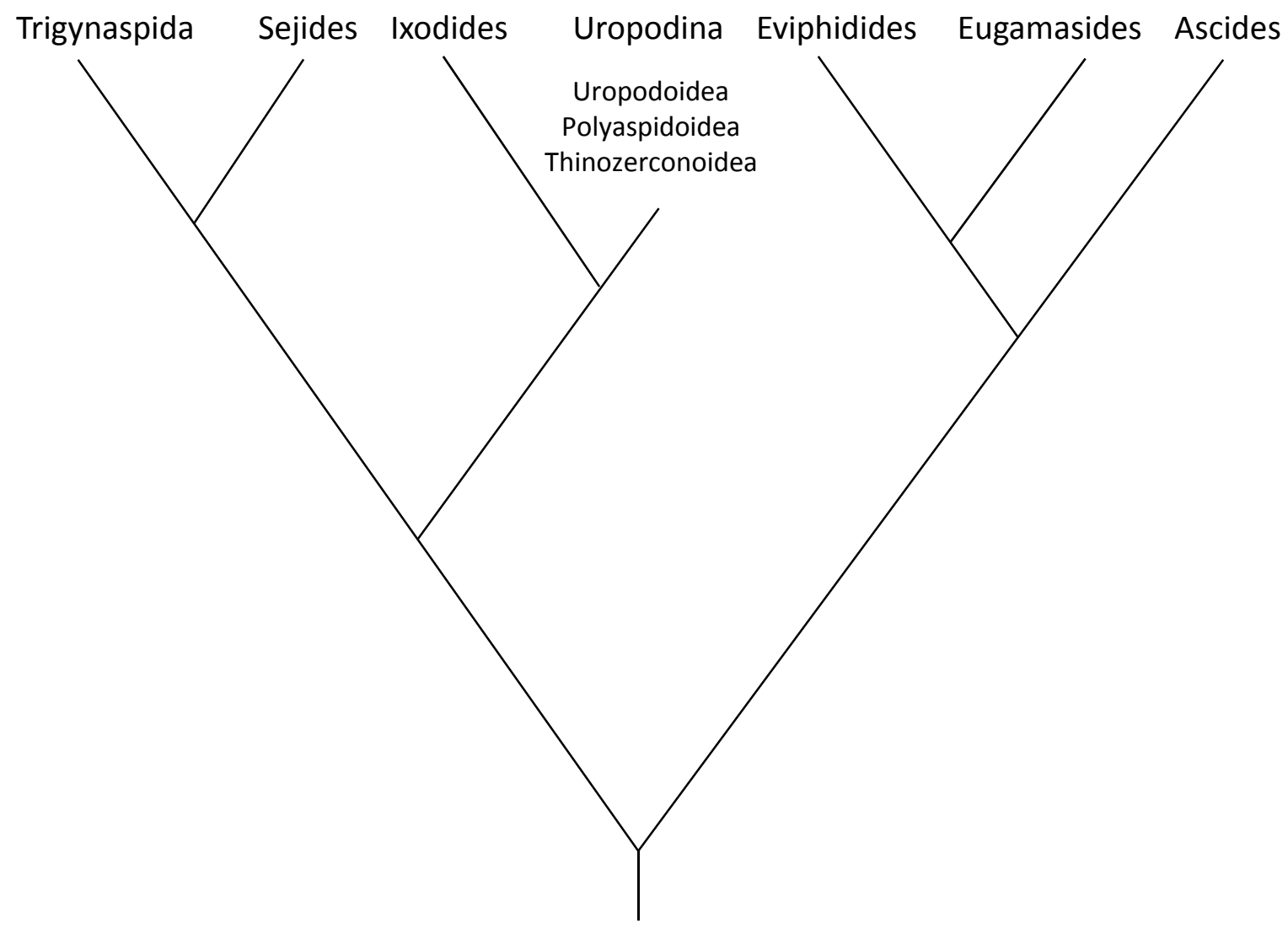

FIGURE 1: Cladogram of the groups of Parasitiformes based on synapomorphies explained by Karg \& Schorlemmer (2008); the subgroups of this taxon are added under the Uropodina: Uropodoidea, Polyaspidoidea and Thinozerconoidea.

erconoidea. Investigations of the leg chaetotaxy of these groups (Krantz \& Ainscough 1990) and of the Ixodides (Edwards \& Evans 1967), however, show that we have to revise this complex of systematic groups.

In the following studies, we analyse the three main groups step by step.

The new species are described, documented and assigned to respective groups. Further, we established cladograms of the newly classified groups.

\section{MATERIAL AND METHODS}

Predatory mites collected in South and Central America are sent to the authors for classification. Prior to studying, the mites are treated with a mix- 
ture of hot glycerin and acetic acid. Subsequently, they are mounted in glycerin, studied and drawn. For preservation, the holotypes and in each case one or several paratypes are mounted in polyvinyllactophenol. Remaining specimens are preserved in 70 per cent alcohol. Deposition of types: Holotypes and paratypes deposited in the arachnological collection of the "Museum für Naturkunde", Invalidenstraße 43, 10115 Berlin, Germany.

Cladograms are established based on synapomorphies of subgroups of the Parasitiformes. Phylogenetic methods by Hennig (1950, 1966, 1994) serve as methodical basis for these studies. The ontogenetic and phylogenetic based nomenclature by Christian \& Karg (2008) is used regarding chaetotaxy of the idiosoma.

Note - Hirschmann (1957) completed for the first time the taxonomy of dorsal setae and annotated the letters in German handwriting into his figures (Figure 14): $\mathbf{r}, \mathbf{R}=$ Randhaare (Marginal setae), $\mathbf{s}, \mathbf{S}=$ Seitenhaare, (Side setae), $\mathbf{z}, \mathbf{Z}=$ Zwischenhaare (Setae between side and interior setae), $\mathbf{i}, \mathbf{I}=$ Innenhaare (Interior setae). Mistakenly, some authors recognized the handwritten German letter I for the letter J.

\section{ANTENNOPHORINA}

BERLESE, 1892 S. LAT.

According to a synapomorphy discovered by Evans \& Till (1979), the Antennophorina comprise the subgroups Trigynaspida and Sejides as a monophyletic unit (Karg \& Schorlemmer 2008). However, in contrast to Evans \& Till (1979), we do not regard Antennophorina and Trigynaspida as synonyms. Our studies showed that the Trigynaspida are a subgroup of the Antennophorina (Figure 1). The last taxon holds the priority. The name Trigynaspida by Camin \& Gorirossi (1955) satisfies the diagnosis of this subgroup.

\section{Trigynaspida Camin et Gorirossi, 1955}

Diagnosis - Three primary shields protecting the genital orifice of females, female sternal shield fragmented (Figure 4), deuto-nymph with podonotal, mesonotal and pygidial shields (Evans \& Till 1979).

This group comprises five super families: Celaenopsoidea Berlese, 1892; Cercomegistoidea Trägårdh, 1938; Fedrizzioidea Trägårdh, 1937; Megisthanoidea Berlese, 1914 and Trigynaspidoidea Camin et Gorirossi, 1955.

\section{Celaenopsoidea Berlese, 1892}

Diagnosis - This subgroup is distinguished from all other subgroups mainly by the position of the male genital orifice, which is shifted to the anterior margin of the sternum. Further, the movable digit is equipped with dendritic or brushlike filamentous excrescences (Karg 1997a: Figures 7, 8, 9).

Three families belong to the super-family (Baker et al. 1958):

- Euzerconidae Trägårdh, 1938

- Diplogyniidae Trägårdh, 1941

- Schizogyniidae Trägårdh, 1950.

\section{Cercomegistoidea Trägårdh, 1938}

Diagnosis - Adults with two or more dorsal shields, palpgenu with six setae, latigynial plates elongated, first sternal setae free or on separate jugular plates, endopodal plates II, III and IV fused and with one or two setae, tectum with a serrated edge.

We distinguish two families:

- Cercomegistidae Trägårdh, 1938

- Pyrosejidae Lindquist et Moraza, 1993.

One new species belongs to the Pyrosejidae, genus Pyrosejus.

\section{Fedrizzioidea Trägårdh, 1937}

Diagnosis - Female with sternal setae st2, st3, and st4 on an undivided shield (Karg 1997a and present publication, Figure 6).

We distinguish two families:

- Fedrizziidae Trägårdh, 1937

- Klinkowstroemiidae Trägårdh, 1946. 


\section{Trigynaspida}

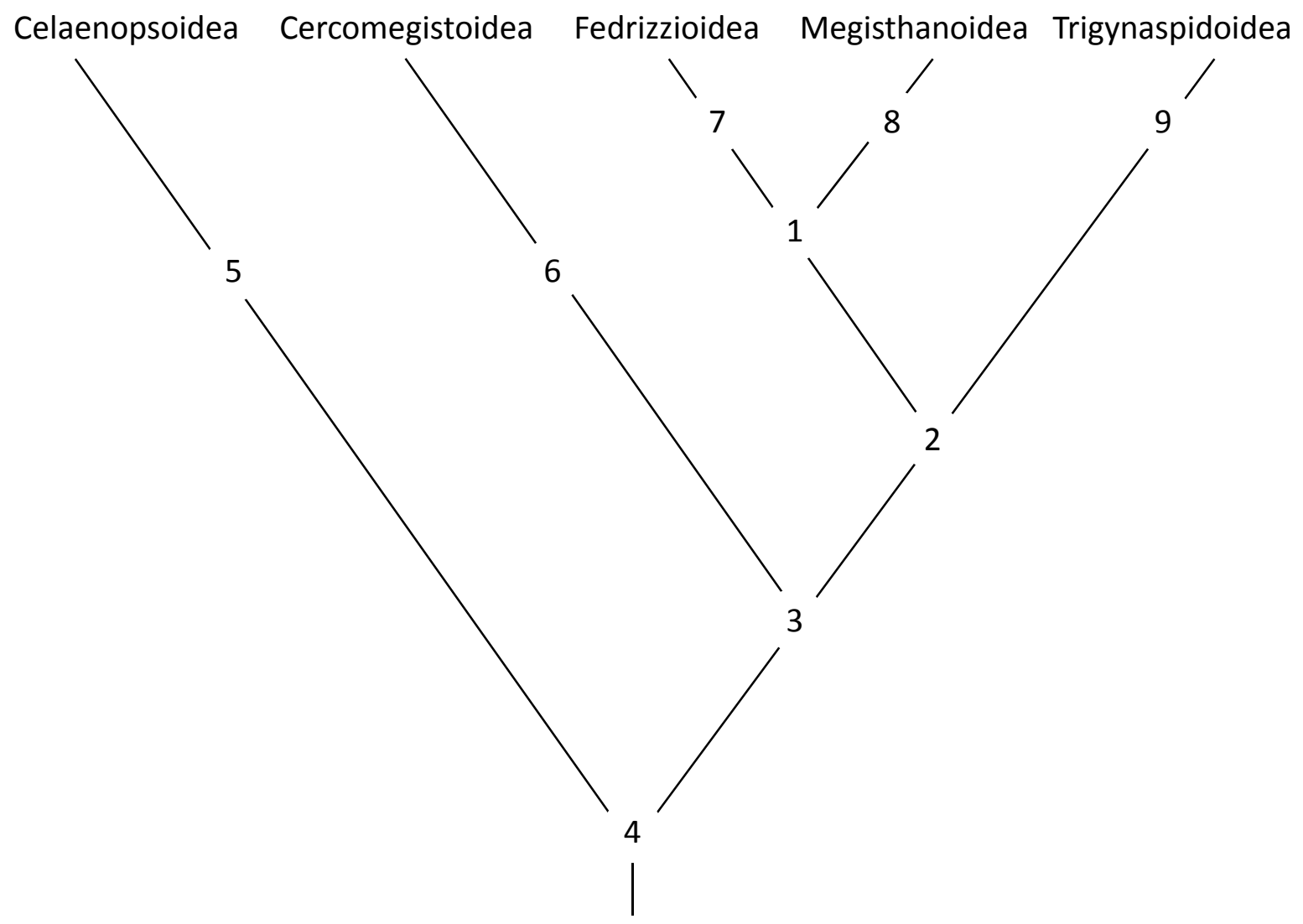

FIGURE 2: Cladogram of the subgroups of Trigynaspida Camin et Gorirossi, 1955, synapomorphies (1 - 4) and autapomorphies (5 - 9), characteristics for the Super-families of Trigynaspida; our present results confirm previous findings:

1 - Sternal shield divided into 2 to 3 parts, as an exception undivided (Figures 4 and 6)

2 - Sternal shield as a rule divided into 2 to 6 parts (Figure 4), Baker $e$ t al., (1958)

3 - Latigynial shields well developed, as a rule separate jugular shields (Figure 4), Karg (1997a)

4 - Three primary shields protecting the genital orifice of females, tarsus IV of adults and deuto-nymphs with 21 setae

(formula: 4, 3/3,1/1,3/3,3), deuto-nymphs with podonotal, mesonotal and pygidial shields (Krantz \& Ainscough 1990, Evans \& Till 1979)

5 - Male aperture at the anterior margin of sternum (Hirschmann \& Zirngiebl-Nicol 1961, Evans and Till 1979)

6 - Adults with two shields on the dorsum (Figure 3)

7 - Female with sternal setae st2, st3 and st4 on an undivided shield (Figure 6), Karg (1997a)

8 - In adults latigynial shields and mesogynial shields coalesced (Hunter \& Costa 1970, Karg 1997)

9 - Sternal shield of adults divided into 4 to 6 parts (Baker et al., 1958)

One new species belongs to the Fedrizziidae. This species differs decisively from the hitherto known species. It proved to be necessary to erect a new genus.
Diagnosis - Adults latigynial and mesogynial shields coalesced (Hunter \& Costa 1970, Karg 1997 a).

We distinguish only one family:

- Megisthanidae Berlese, 1914. 


\section{Trigynaspidoidea Camin et Gorirossi, 1955}

Diagnosis - Sternal shield of adults divided into four to six parts (Baker \& others 1958). This indicates that in this group, the division of the sternal shield as a characteristic attribute for the Trigynaspida is more pronounced than in the other superfamilies.

We distinguish only one family:

- Trigynaspidae Camin et Gorirossi, 1955.

Relation of the groups - From our relationship analysis of the super-families of the Trigynaspida we found the synapomorphies 1 to 4 from which we generate a cladogram (Figure 2).

The super-families are characterized by their corresponding diagnoses, but mainly by the autapomorphies 5 to 9 as in the cladogram (Figure 2).

\section{New species}

Two new species from Ecuador belong to the Trigynaspida. One species is assigned to the superfamily Cercomegistoidea, family Pyrosejidae, genus Pyrosejus. A second species belongs to the superfamily Fedrizzioidea, family Fedrizziidae, new genus: Holostethus n. gen.

\section{Pyrosejidae Lindquist et Moraza, 1993}

Diagnosis - Adults with two sub equal dorsal shields, pro-dorsum slightly hypo trichous, post-dorsum hypo trichous, near setae z3 backwards separate marginal shields bearing some of s$\mathrm{S}$ and $\mathrm{r}-\mathrm{R}$ setae, female mesogynial shield small but well sclerotized, ventrianal shield expansive, continuously united with peritrematal-exopodal and marginal shields and caudal with post-dorsum.

\section{Pyrosejus Lindquist et Moraza, 1993}

Diagnosis - Considering the newly detected species we have revised the diagnosis of the genus Pyrosejus. Pro-dorsum with 15 - 16 pairs of setae, post-dorsum with $6-8$ pairs of setae, marginal shields on the anterior part $5-6$ pairs of setae, on the posterior part $7-8$ pairs of setae with some of them ventrally localized, tarsus of leg I with welldeveloped paired claws, fixed digitus of chelicerae with minute pilus dentilis and a row of several teeth, movable digitus proximal with one big tooth and distal with a row of smaller teeth.

\section{Pyrosejus verticis n. sp.}

Holotype - $\subsetneq$ Ecuador, 1989, Province Pichincha, between Pifo and Papellacta, $4100 \mathrm{~m}$ a.s.l. from felt-like debris under Jumble of dicotyledon, creeping to $2 \mathrm{~m}$ height on a tree.

Paratypes - 9 \%, collectors I. Loksa and A. Zicsi.

Etymology - As to the well-developed vertex with relative long setae i1, z1, z2 and s1.

Diagnosis - Most dorsal setae remarkably long: 60 to $102 \mu \mathrm{m}$, on the post-dorsum setae I2 and Z2 absent, $q$ between mesogynial shield and a median incision of the ventrianal shield a single distinct triangular shield (Figures 3, 5).

Description - Idiosoma o $348-374 \times 244-270$ $\mu \mathrm{m}$, brown.

Dorsum: Divided into a pro-dorsum, a postdorsum and backwards setae z3 separate marginal shields, dorsal shields and the posterior part of venter with scale like patterns, posterior margin of the post-dorsum crenellated, most of the dorsal setae remarkably long, longest setae I1, I3 and s4: $=102$ $\mu \mathrm{m}, \mathrm{i} 2=65, \mathrm{i} 3=60, \mathrm{i} 4=\mathrm{i} 5=85, \mathrm{z} 1=48, \mathrm{z} 4=77$, $\mathrm{s} 3=92, \mathrm{~s} 5=78, \mathrm{r} 3=70, \mathrm{I} 4=75, \mathrm{Z} 1=\mathrm{Z3}=95 \mu \mathrm{m}$ long, setae at the vertex and at the posterior margin shorter however not reduced: i1 $=46, \mathrm{z} 1=65, \mathrm{~s} 1=$ $18, \mathrm{z} 2=\mathrm{r} 2=20, \mathrm{I} 5=31 \mu \mathrm{m}$ long.

Venter: With mesogynial-shield well developed and nearly rectangular, posterior part of the latigynial-plates broadened and with a second seta, the first seta between coxae III and IV, the first sternal setae on separate triangular plates, the second pair on an oval shield, also the third pair on a smaller oval shield, the fourth pair free on the soft cuticle, ventrianal-shield fused with the dorsum and with lateral and peritrematal shields, median of the ventrianal shield with a deep incision which is broadened posterior of the mesogynialshield and accommodates for a single triangular plate, surface of the ventrianal shield similar to the 


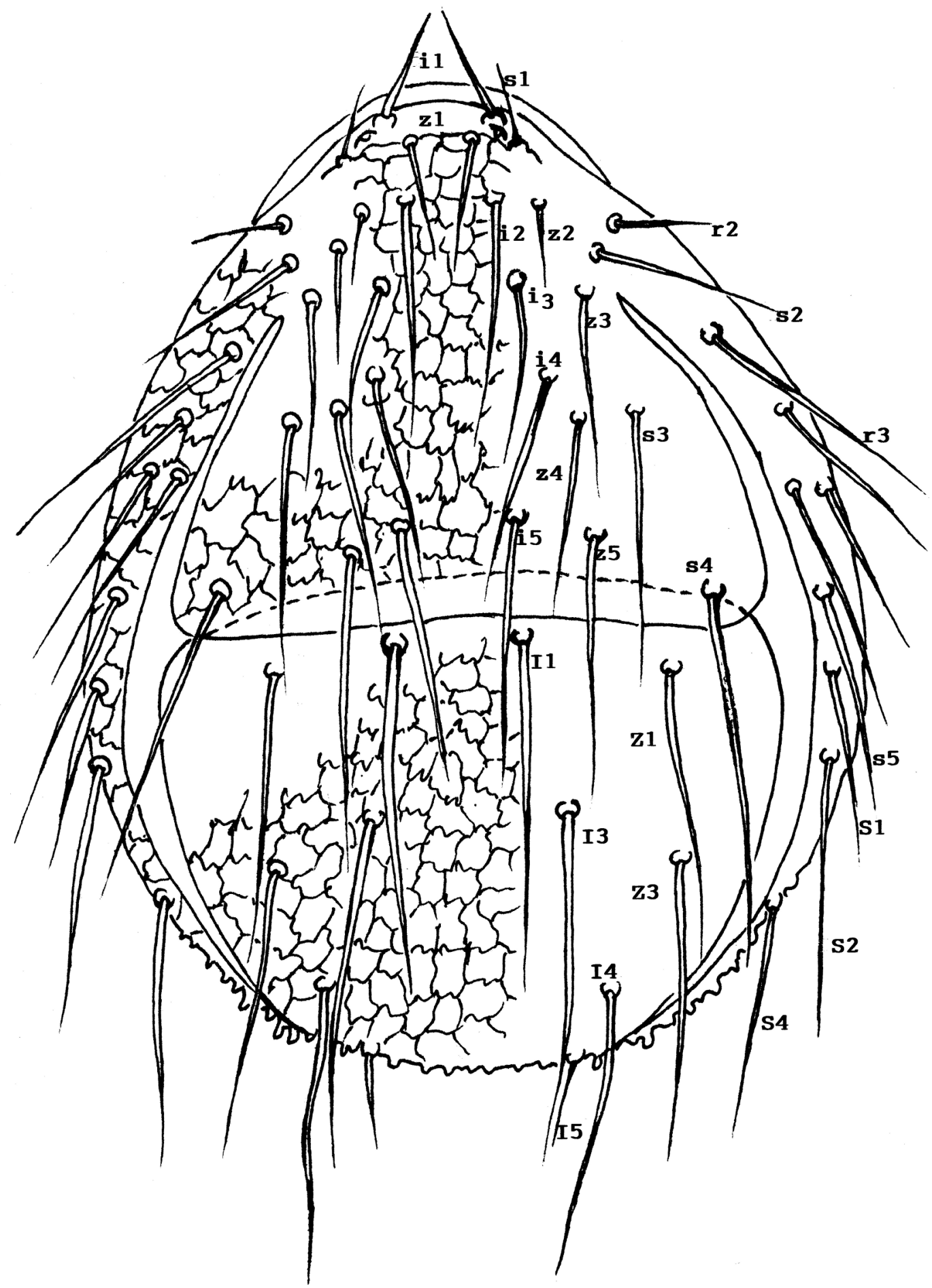

FIGURE 3: Pyrosejus verticis n. sp. Female. Dorsum, $348-374 \mu \mathrm{m}$ long. 


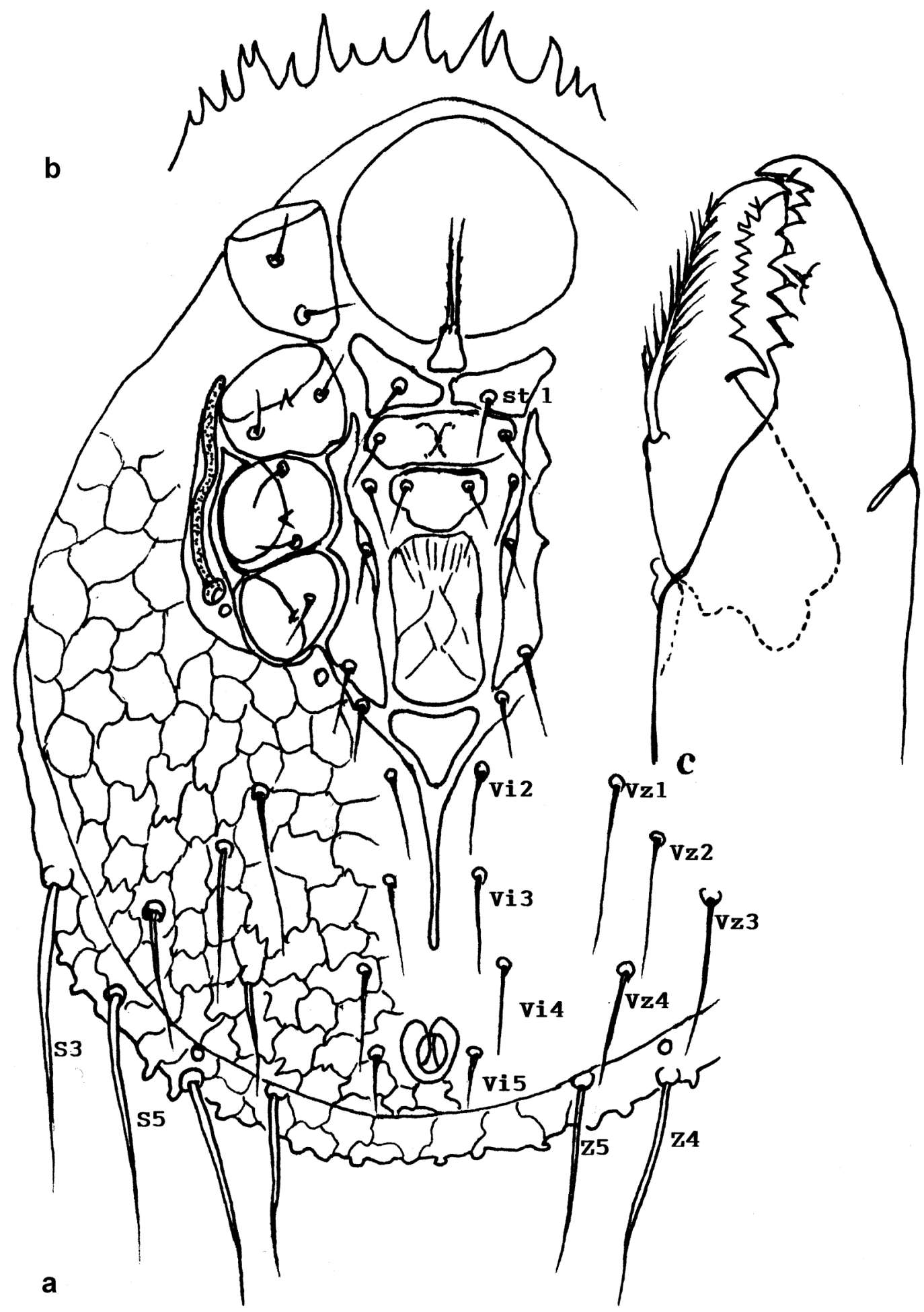

FIGURE 4: Pyrosejus verticis n. sp. Female. a - Venter; b - Tectum, $34 \mu \mathrm{m}$ wide; c - Chelicera, $35 \mu \mathrm{m}$ long. 
dorsum with scale like patterns, setae of the anterior part of the venter remarkably short, st $1=34 \mu \mathrm{m}$ long, the other 18 to $26 \mu \mathrm{m}$ long, setae of the posterior part mostly longer, $\mathrm{Vi2}=\mathrm{Vi} 3=34, \mathrm{Vi} 4=37$, $\mathrm{Vz} 1=\mathrm{Vz} 2=\mathrm{Vz} 3=50, \mathrm{Vz} 4=44 \mu \mathrm{m}$ long, a strip of the marginal shields ventrally visible bearing the following dorsal setae: $\mathrm{S} 3=\mathrm{S} 5=80, \mathrm{Z} 4=71, \mathrm{Z} 5=60$ $\mu \mathrm{m}$ long, the anus remarkably small and with a pair of short adanal setae: $\mathrm{Vi} 5=25 \mu \mathrm{m}$ long.

Gnathosoma: Tritosternum with two laciniae recognizable, anterior margin of tectum denticulate with teeth of different size, margins of hypostome fused, hypostomatic setae on the palpal coxae 9 to $20 \mu \mathrm{m}$ long: $\mathrm{C} 1=20, \mathrm{C} 2=18, \mathrm{C} 3=13, \mathrm{C} 4=9 \mu \mathrm{m}$ long, paralaciniae $16 \mu \mathrm{m}$ long with a $8 \mu \mathrm{m}$ wide dented basis, chelicerae strong and stout, $22 \mu \mathrm{m}$ wide, digitus mobilis $34 \mu \mathrm{m}$ long, with a big proximal tooth and $9-10$ small teeth, digitus fixus with $7-8$ medium-sized teeth.

Legs: I = 322, II = 261, III = 261, IV = $356 \mu \mathrm{m}$ long appropriate an idiosoma $348 \times 244 \mu \mathrm{m}$, tarsi I to IV with paired claws, at leg I longer however without pretarsus, at leg II to IV shorter and with pretarsus.

Taxonomy - Lindquist \& Moraza (1993) described one new species of the new genus Pyroseius and a second form, which they consider to be a second new genus. However, our new species represents beyond its own characteristics also features of both, P. prionotus Lindquist et Moraza, 1993 and the assumed second new genus (Table 1). That means we have found an intermediate species. The three forms therefore are separate species of the same genus.

\section{Fedrizziidae Trägårdh , 1937}

Diagnosis - We have revised the diagnosis of this family considering the new genus Holostethus n. gen.

Holodorsal shield with numerous setae, several unpaired, marginal shields developed, posterior parts or lateral and posterior parts turned down to the venter, o sternogynial shield shaped somewhat like an inverted bell-jar, latigynial shields long and narrow, mostly a jugular shield separated from sternal shield, o venter with anal shield or ventrianal shield, $\sigma^{\prime}$ genital orifice oval or circular between coxae II - III, digiti of chelicerae dentate, digitus mobilis with long hyaline processes two of them blade-like and serrate, the other filamentous, shape of tectum like a tongue, palptarsal apotele 2-tined.

\section{Holostethus n. gen.}

Etymology - Holo $=$ fused, entire, stethos $=$ thorax, as to the fused shields of the sternal region.

Type-species - Holostethus longosetis n. sp.

Diagnosis - Characteristics conform with the diagnosis of the Fedrizziidae, however different to the hitherto known genera of the family. Remarkable characteristics of the new genus are the fused sternogynial -, sternal - and jugular shields, the separate endopodal shields, additional preendopodal shields, a mesogynial shield and claws at the first pair of legs. Further in $o$, behind coxae IV, a big ventrianal shield is developed whereas in the hitherto known genera only a small shield, $1 / 3$ to $1 / 2$ the distance coxae IV to the anus, is developed.

Hitherto one species was detected in soilsamples from Ecuador:

TABLE 1: Diagnostic features of Pyrosejus species.

\begin{tabular}{|c|c|c|c|c|c|}
\hline Species & pro-dorsum & post-dorsum & sternal region & genital region & ventrianal shield \\
\hline P. prionotus & $\begin{array}{c}\text { setae at vertex well } \\
\text { developed }\end{array}$ & setae I1-I5 present & $\begin{array}{c}\text { st2, st3 on separate } \\
\text { plates }\end{array}$ & $\begin{array}{c}\text { one seta on latigynial } \\
\text { shield }\end{array}$ & anterior with incision \\
\hline P. verticis & Same as above & setae I2 absent & Same as above & $\begin{array}{c}\text { two setae on latigynial } \\
\text { shield }\end{array}$ & $\begin{array}{l}\text { incision with } \\
\text { triangular plate }\end{array}$ \\
\hline P. sp. n. gen.? & setae s1, s2 reduced & Same as above & $\begin{array}{l}\text { st } 2, \text { st } 3 \text { on a connected } \\
\text { plate }\end{array}$ & $\begin{array}{c}\text { one seta on latigynial } \\
\text { shield }\end{array}$ & no incision \\
\hline
\end{tabular}




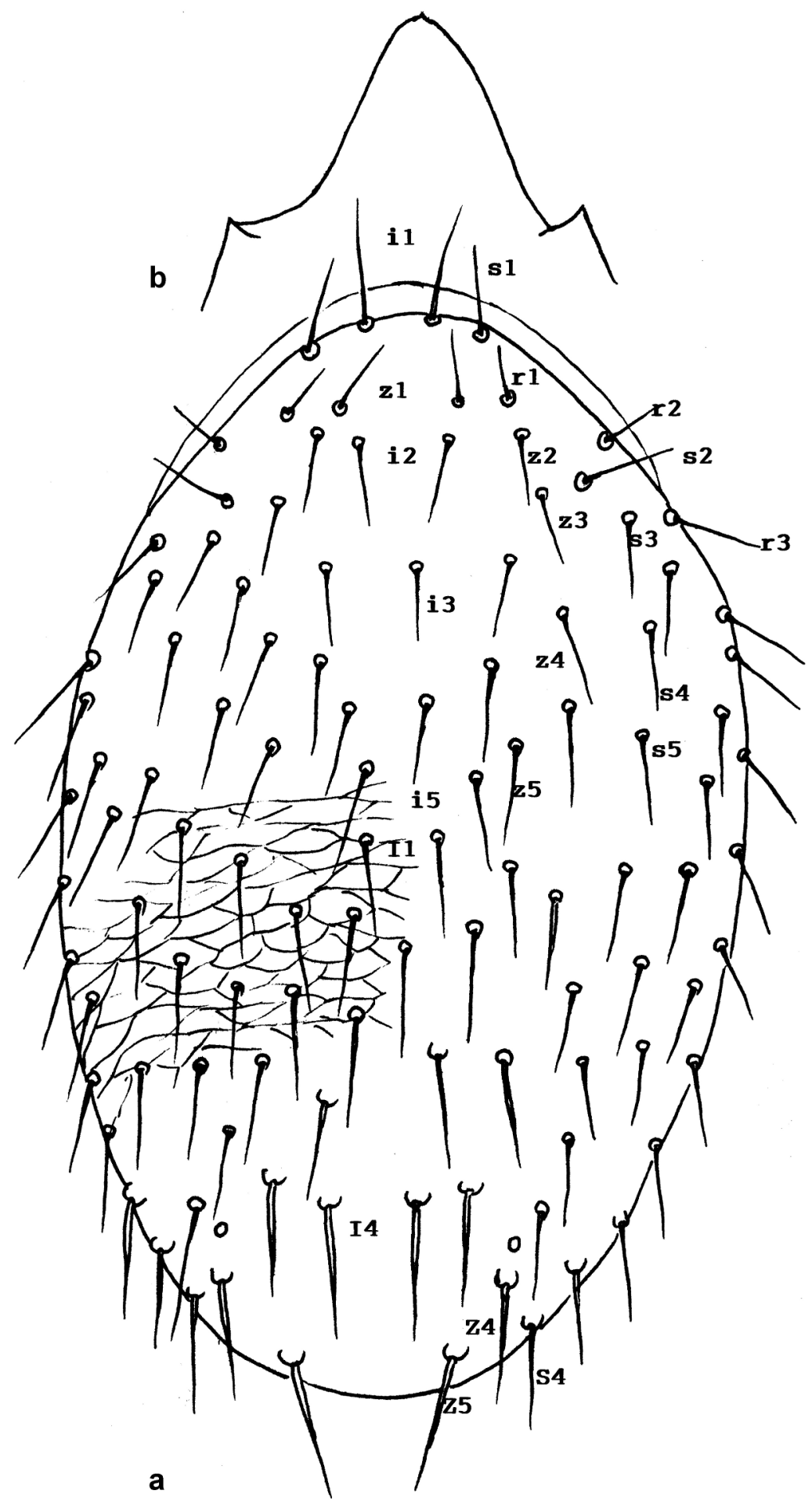

Figure 5: Holostethus longosetis n. sp. Female. a - Dorsum, 957 - $1092 \mu \mathrm{m}$ long; b - Tectum, $88 \mu \mathrm{m}$ wide. 
Karg W. and Schorlemmer A.

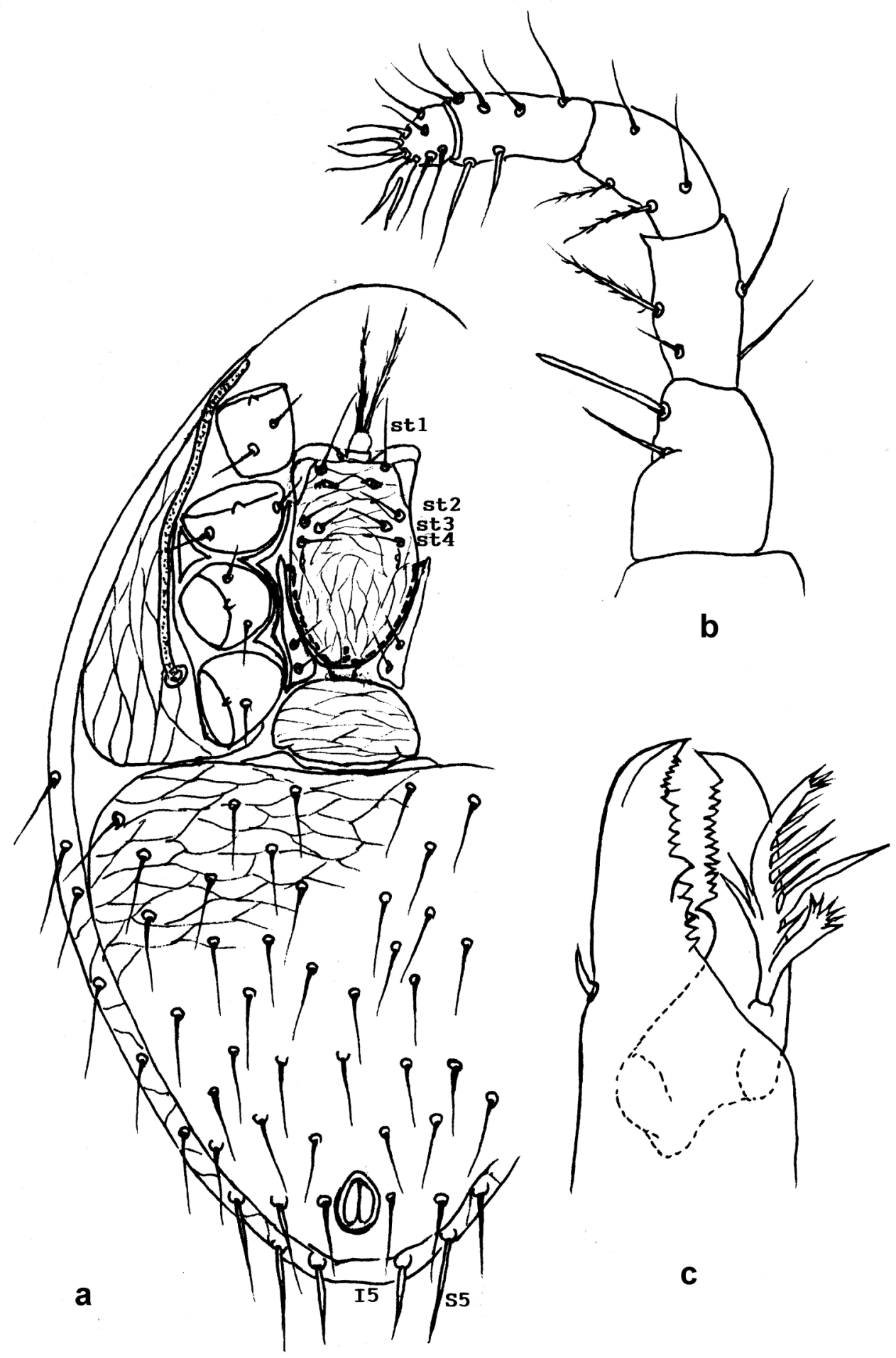

Figure 6: : Holostethus longosetis n. sp. Female. a - Venter; b - Pedipalpus, $245 \mu \mathrm{m}$; c-Chelicera, $88 \mu \mathrm{m}$ long. 


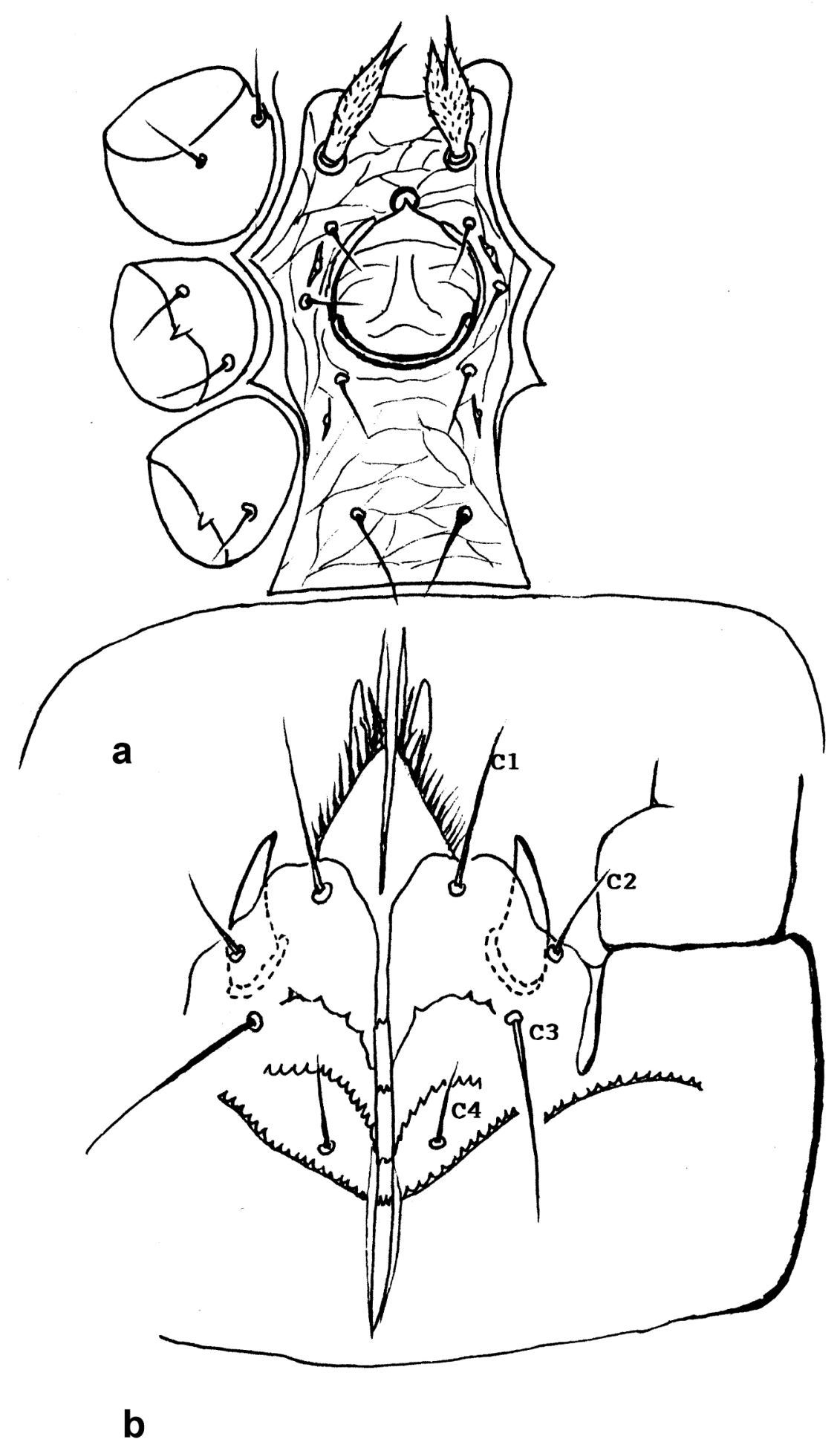

Figure 7: Holostethus longosetis n. sp. a - Male Sternum, $350 \mu \mathrm{m}$ long; b - Female Hypostome, 175 m long. 


\section{Holostethus longosetis n. sp.}

Holotype - o Ecuador, 1989.

Paratypes -3 \%, $2 \sigma^{\prime \prime}, 1$ \% before hatching out of the deuto-nymph, 2 deuto-nymphs, 1 proto-nymph.

Etymology: longus $=$ long, seta $=$ hair, as to the relative long hairs on the dorsum.

Diagnosis - Most of dorsal setae nearly as long as the distances to the next setae in series, $\sigma$ first sternal seta shaped like a leaf, $o$ digitus mobilis of chelicerae with one big proximal tooth and $11-12$ small teeth, digitus fixus proximal 3 small, in the middle 3 bigger teeth, in front of it, 4 small and distal $4-5$ very little teeth (Figures 5, 6, 7).

Description - Idiosoma @ 957-1092 × 650-696 $\mu \mathrm{m}$.

Dorsum: Oval, brown, surface with net-like patterns, with 53 - 56 pairs of setae, by unpaired setae symmetry disturbed, most of setae $70-74 \mu \mathrm{m}$ long, needle-like, posterior setae I4, Z3, Z4 and Z5 somewhat stronger, i1 $=70, \mathrm{i} 5=70, \mathrm{I} 1=70, \mathrm{I} 4=74$, $\mathrm{Z} 5=70 \mu \mathrm{m}$ long, several setae on the anterior part shorter, $\mathrm{z} 1=53, \mathrm{i} 2=63, \mathrm{r} 2=32, \mathrm{r} 3=52 \mu \mathrm{m}$ long, at the vertex the anterior part of a marginal shield recognizable, the main part of this shield turned down to the venter.

Venter: Therefore marginal setae appear ventral, at the posterior part S5 (69 $\mu \mathrm{m}$ long) and I5 (60 $\mu \mathrm{m}$ long), ventral shields with net-like patterns, peritrematal shields well developed, peritremata reaching front margin of coxae I, remarkable big ventrianal shield with 20 pairs of setae and $4-5$ unpaired setae, mostly 54-56 $\mu \mathrm{m}$ long, the paranal setae $60 \mu \mathrm{m}$ long, between coxae III/IV the posterior margin of the sternogynial shield shaped like an inverted bell-jar, between coxae II a homogenous sternal shield with four pairs of sternal setae, st1 remarkably long: $46 \mu \mathrm{m}$, st2, st 3 and st 4 localised closely together forming the figure of a triangle, setae $27-30 \mu \mathrm{m}$ long, sternal shield and sternogynial shield fused, between the sternogynial shield-part and coxae III/IV strip-like endopodal shields and small latigynial shields, each of these shields bearing 2 setae, between sternogynial shield and ventrianal shield a semicircular mesogynial shield, in front of the sternal-sternogynial shield a tritosternum with two laciniae and flanked by a pair of slender preendopodal shields.

Gnathosoma: Tectum tongue-like, hypostomatic groove slender, inside with 3 to 4 hypognathal transverse lines, outside on the palpal coxae 4 longer dented lines, setae on palpal coxae of different length, $\mathrm{C} 1=44, \mathrm{C} 2=30, \mathrm{C} 3=60, \mathrm{C} 4=25$ $\mu \mathrm{m}$ long, corniculi horn-like, laciniae with many fine fringes, a pair of stronger styli and a pair of longer points in the middle, digiti of chelicerae multidentate, palps: paraxial posterior part of palptrochanter swollen, anterior with 2 setae, 26 and 37 $\mu \mathrm{m}$ long, the longer setae slightly spatulate, most of the palp-setae needle-like, however inside 2 setae at the palp-genu (26, $28 \mu \mathrm{m}$ long) and one seta at the palp-femur (36 $\mu \mathrm{m}$ long), pinnate.

Legs: $\mathrm{I}=748, \mathrm{II}=609, \mathrm{III}=566, \mathrm{IV}=844 \mu \mathrm{m}$ long if the idiosoma $1092 \mu \mathrm{m}$ long, tarsus I with a pair of claws without pre-tarsus, tarsi II to IV with pretarsus and two claws.

Idiosoma o" 957 - 1044 x $653-696 \mu \mathrm{m}$, dorsum similar as in the female, venter also with a big ventrianal shield, between coxae II, III and IV however a homogeneous sternum fused with the endopodal shields, a circular genital shield between coxae III, sternum with five pairs of setae, extraordinarily remarkable the first pair of sternal setae: leaf-like, 68 $\mu \mathrm{m}$ long and $26 \mu \mathrm{m}$ wide, the other setae $27-28$ $\mu \mathrm{m}$ long, digiti of the chelicerae with many teeth as in the female, outside the hypostomatic groove deviating from the $o$ between $\mathrm{C} 3$ and $\mathrm{C} 4$ two areas densely covered with small teeth.

Idiosoma deuto-nymph $609-670 \times 470-478 \mu \mathrm{m}$, dorsum and legs similar as in the female, venter also with a big ventrianal shield, between coxae II, III and IV however a homogeneous sternum fused with the endopodal shields bearing five pairs of needle-like setae, paranal setae are remarkably short: $14 \mu \mathrm{m}$, chelicerae as in the adults.

Idiosoma proto-nymph 435 × $390 \mu \mathrm{m}$, dorsum with lower number of setae as in the deuto-nymph, legs as in the other stages, sternum with three pairs of setae, ventrianal shield as in the other stages, peritremata very short. 


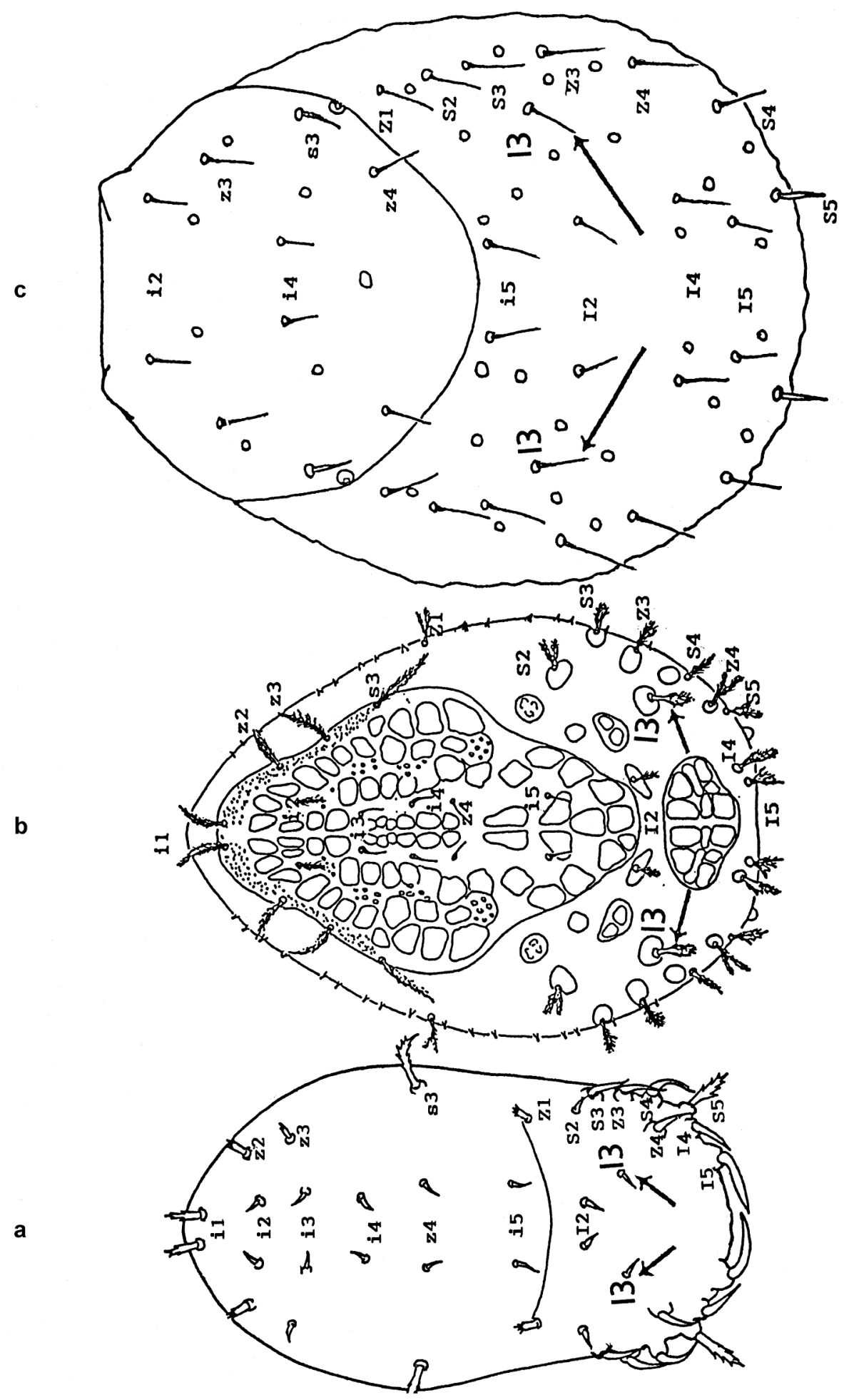

FIGURE 8: Dorsum of larval stages in different groups of Margotrichina showing the shifting of setae I3, ancestrally caused by development of a special pygidial shield within the posterior rows of setae; a - Microgyniina, $220 \mu \mathrm{m}$; b - Uropodina, 250 - $380 \mu \mathrm{m}$; c Ixodides, 500-600 $\mu \mathrm{m}$ long (after Hirschmann 1961 and Karg \& Schorlemmer 2008). 

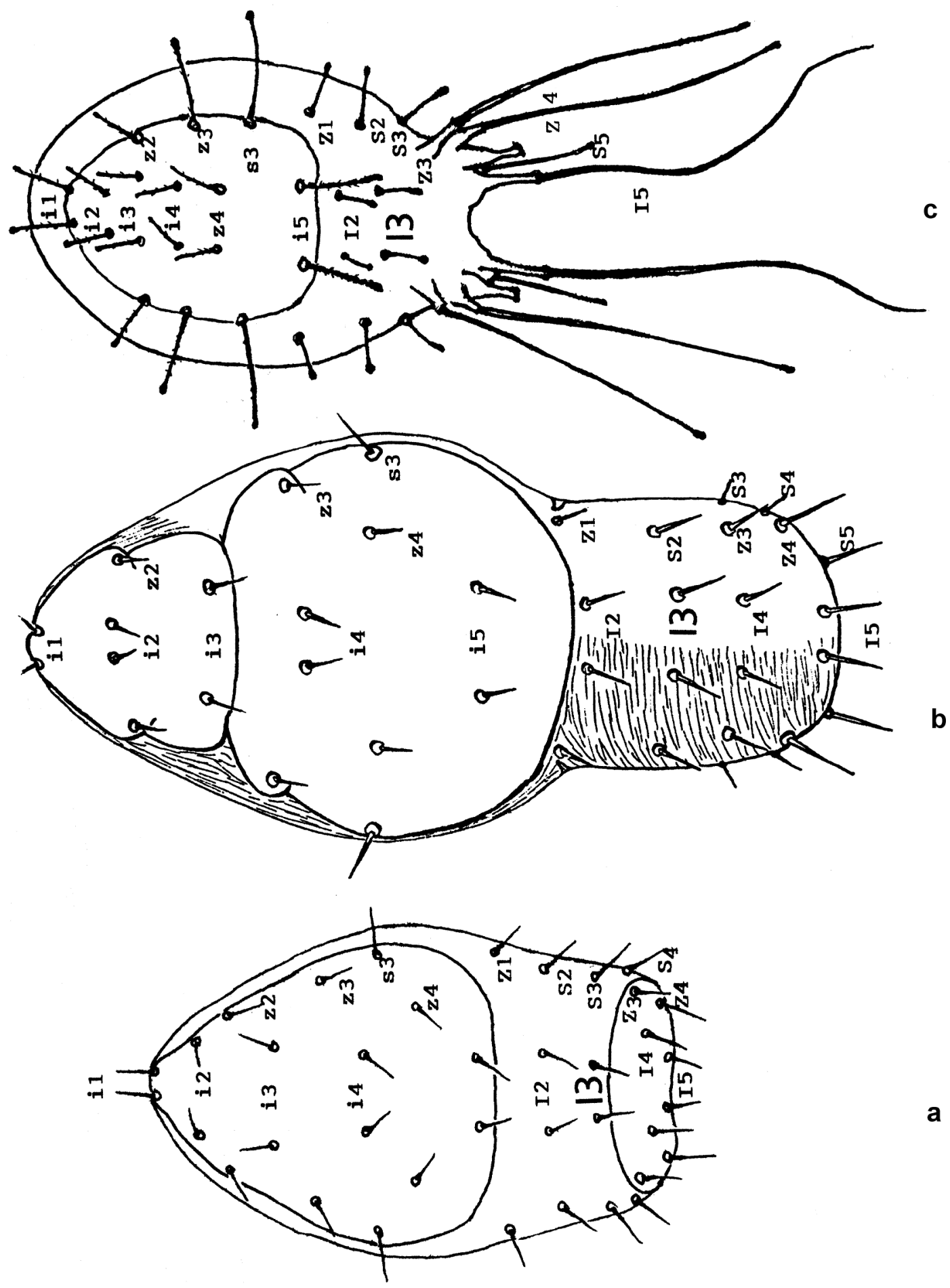

b

FIGURE 9: Dorsum of larval stages in groups of Parasitiformes showing undisturbed transverse rows of setae which we interpret in accordance with Christian \& Karg (2008) as residues of an ancestral body segmentation; a - Gamasina - Ascides, 270 - $290 \mu \mathrm{m}$; b - Gamasina - Eugamasides, 130 - $455 \mu \mathrm{m}$; c - Antennophorina - Sejides, 290 - $370 \mu \mathrm{m}$ long. Some groups have developed special shaped setae, which we have to regard as secondary developments (some modified after Karg 1962, 1965 and Hirschmann 1957). 


\section{Margotrichina}

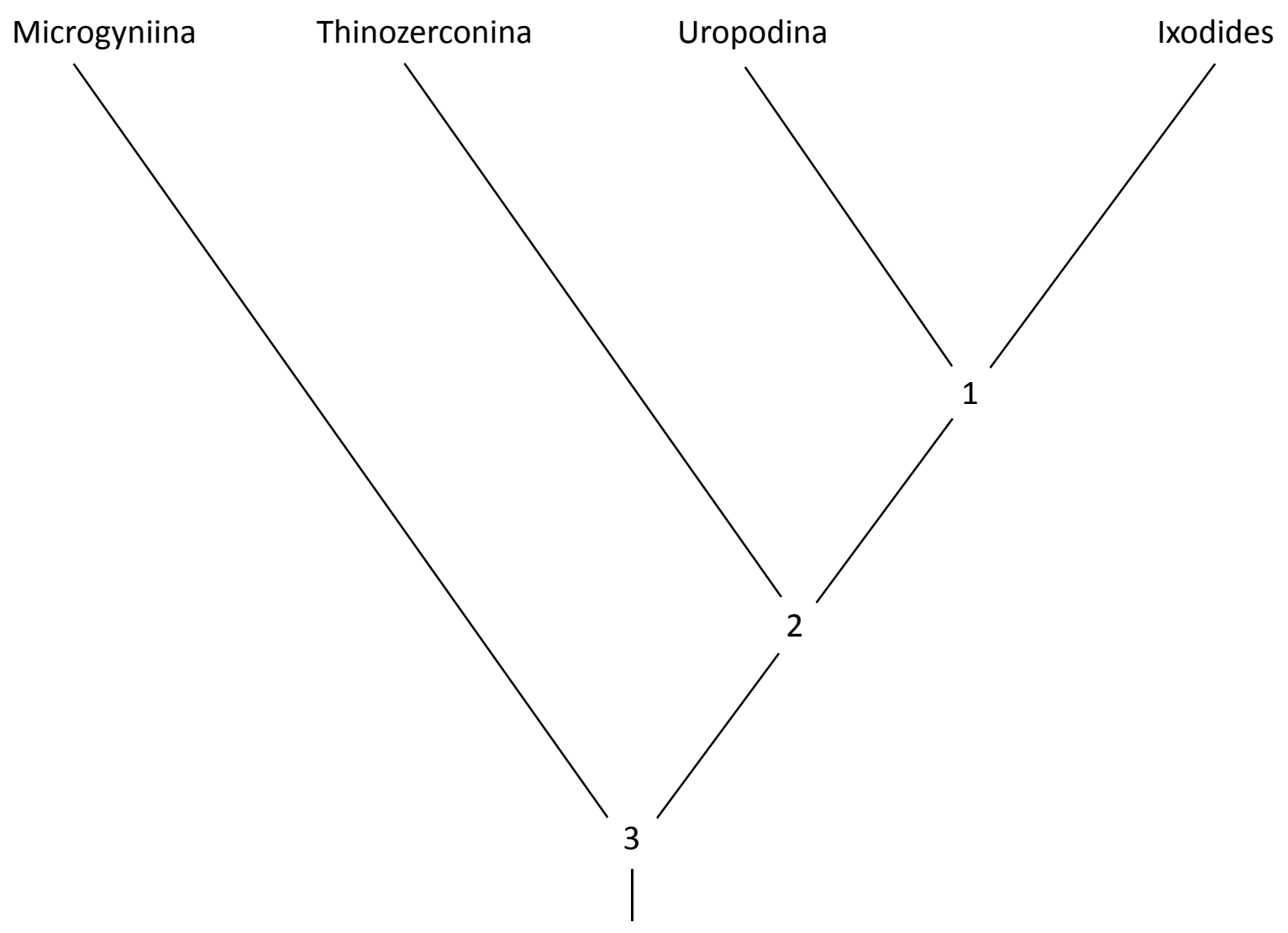

FIgURE 10: Cladogram of the subgroups of the Margotrichina Karg et Schorlemmer, Synapomorphies 1-3, characteristics for the subgroups of the Margotrichina; our present results confirm previous findings:

1 - Genua I - IV with four or fewer dorsal setae (Edwards \& Evans 1967, Krantz \& Ainscough 1990), phoretic respectively parasitic stages with eu-anal setae (Karg \& Schorlemmer 2008)

2 - Tibia I - IV with three or more dorsal setae, femur IV of adults with six or seven setae, third hypostomatic setae well behind the second hypostomatic setae (Karg 1989, Krantz \& Ainscough 1990)

3 - In the larva, position of setae pair I3 on the dorsum marginal shifted (Figure 8), dorsum of adults with marginal grooves (Hirschmann \& Zirngiebl-Nicol 1961, Karg \& Schorlemmer 2008).

\section{MARGOTRICHINA}

\section{KARG ET SCHORLEMMER, 2008}

Hitherto, the Ixodides, as an economic and medical significant group, obtained a higher systematic category than each of the remaining Parasitiformes groups (Walter \& Proctor 1999, Krantz \& Walter 2009). Canestrini (1891) named these groups Mesostigmata although stigmata are also localized laterally in the middle of the body in a group of Ixodides. While this "Non-tick grouping" is without a doubt a practical zoological unit for processing and publications, it is without systematic and phylogenetic basis.

Phylogenetic investigations in the past years by Karg and Schorlemmer (2008) led to new insights into the relationship of the Parasitiformes subgroups Uropodina, Ixodides and Gamasina. The Ixodides and the Uropodina have four synapomorphies in common. They are more closely related to each other than to any other mite group. They have emerged from one common original group. 
Analyses of functional morphology and behaviour of the Uropodina revealed how special organs and behaviour for parasitism developed.

New results by Dowling \& Oconnor (2010) suggest that parasitism in Dermanyssoidea has evolved even repeatedly in this group. It becomes obvious that parasitic groups did not appear spontaneously and separately in evolution. These groups and their special organs suited for parasitism developed step by step out of free-living base groups.

Ixodides and Uropodina had to be united in one common group: Margotrichina Karg et Schorlemmer, 2008. The investigations were based on phylogenetic methods by Hennig $(1950,1966,1994)$. Unfortunately, our new results could not yet be included in the manual by Krantz \& Walter (2009).

The relationship of Holothyrida and Opilioacariformes remains unclear (Walter \& Proctor 1999, Krantz \& Walter 2009). We compared publications by Baker (1958), Evans \& Till (1979) and Krantz \& Walter (2009). For that it is doubtful whether the Holothyrida are a monophyletic group. Krantz \& Walter (2009) already pointed out several characteristics of subgroups of the Holothyrida, which direct to various groups of Parasitiformes. However, the Ixodides were excluded. Lehtinen (1999) and Moraza (2004) proposed a connection of Holothyrida and Ixodides, but their arguments turned out to be unconvincing (Krantz \& Walter 2009).

In Karg (1989) the taxon Uropodina was revised and divided into three subgroups; Uropodoidea, Polyaspidoidea (including Trachytidae, Polyaspidae) and Thinozerconoidea (Figure 1). The present study investigates the chaetotaxy of extremities. It becomes clear that two subgroups of the Uropodina, specifically the Uropodoidea and the Polyaspidoidea, have apomorphic chaetotaxic attributes similar to the Ixodides: Genua I to IV with four or fewer dorsal setae formula 1 - 2/1, 2/1 - (1) (Edwards \& Evans 1967, Krantz \& Ainscough 1990).

However, this does not hold for the third subgroup of the Uropodina, the Thinozerconina. In this group, genua I to IV have five and more dorsal setae. Overall, all three subgroups have common chaetotaxic characteristics: Tibia I-IV with three or more dorsal setae, femur IV of adults with six or seven setae (Krantz \& Ainscough 1990).

We further investigated the phylogenetic relationships of a fourth group, the Microgyniina: The key of suborders by Evans \& Till (1979) relates this group to the Gamasina through diagnostics characteristics. In contrast, the key to families by Krantz \& Ainscough (1990) assigns the Microgyniina to the Sejina. We hence performed a thorough analysis of characteristics including larval-systematic comparisons.

\section{Microgyniina Trägårdh, 1942}

Diagnosis - Sternal shield fragmented, one pair of epigynial setae, male genital aperture posterior to coxae II, hypostomatic setae 2 and 3 inserted at more of less the same level, femur IV of adults and deuto-nymphs with seven setae.

We distinguish two families:

- Nothogynidae Walter et Krantz, 1999 One genus:

- Nothogynus Walter et Krantz, 1999

- Microgyniidae Trägårdh, 1942 Two genera:

- Microsejus Trägårdh, 1942

- Microgynium Trägårdh, 1942

Systematics - A pedunculate phoretic deutonymph occurs during the developmental cycle of the species of these groups. Adults have marginal shields or marginal grooves, in parts mesonotal and pygidial shields on the dorsum. These special characteristics are developed also in the large group of Uropodina Kramer. Krantz \& Walter (2009) also recognized these connections.

From investigations of the chaetotaxy in the larval stage of Microgyniina, further important characteristics are detected: On the posterior part of the dorsum a row of setae ancestrally localized in the middle is displaced to the margin (Figure 8a). This synapomorphy is characteristic for the Uropodina and also for the Ixodides (Figures $8 \mathrm{~b}$ and $\mathrm{c}$ ). These groups have been classified as Margotrichina by Karg \& Schorlemmer (2008). The Uropodina show 
that throughout evolution a small shield must have originally developed in the middle of the posterior part of dorsum shifting setae simultaneously to the margin (Figure 8b).

In the Ixodides, adaptation to blood sucking and stretching the body led secondarily to an elimination of the shield. In the Microgyniina, sclerotisation of the larva is so weak that the ancestral shield is also not detectable. The abnormal position of setae, however, is preserved.

In the other two large groups of Parasitiformes the Antennophorina and the Gamasina - the larval setation has been preserved consistently as in the ancestral figuration (Figure 9).

Based on these new insights, we integrate the Microgyniina into the Margotrichina. A cladogram is drawn based on synapomorphies (Figure 10).

\section{GAMASINA LEACH, 1815}

Groups of the Gamasina belong to the beststudied Acarina. Most species are predators and act as natural regulators in ecosystems. Several species are used as biocontrol agents (Berker 1956, Dosse 1956, Begljarov 1967, Karg 1961, 1972, 1989, 1993 a, 1994 a, Karg \& Freier 1995). New species are, however, constantly discovered in tropical rainforests.

Classification can be more and more based on synapomorphies. Results by Alberti (1995, 2000 a, b) concerning special forms of sperm and by Klompen (2000) concerning nucleotide sequences together with detected autapomorphies (Karg 2006), lead to a revision of the systematics.

The Gamasina were divided into three main groups (Figure 1) which are divided into superfamilies: Eviphidides (three super-families), Eugamasides (two super-families) and Ascides (one super-family). The origin and evolution during past geological periods were elucidated step by step (Karg 1982, 1991, 1994 b, 1996, 1997 b, 1998, 2000 a, b, 2003 a, b, 2006, 2007, Karg \& Schorlemmer 2008, 2009).

In the present investigation we detected two new species of the less known genus Gamasiphoides
Womersley, 1956. This genus belongs to the family of the Gamasiphidae from the super-family Rhodacaroidea, main group Eugamasides.

\section{Gamasiphidae Lee, 1970}

Diagnosis - Adults with well-developed peritrematal and ventrianal shields, peritrematal shields fused with exopodal shields IV, in female sternal setae pair st3 - st3 with close distance and displaced anterior, inner setae at the palp-genu most without prongs or only with one very small prong.

\section{Gamasiphoides Womersley, 1956}

Diagnosis - Adults with a holonotal shield, which may or may not be fused to ventro-anal shield, peritrematal shields fused to exopodal IV shields, exopodal III shields are split, two pairs of distinct pre-endopodal shields, in females sternometasternal shield fused to endopodals II and III, endopodal IV shields separate and well developed, in males sterno-genital shield fused to endopodals II, III and IV, spermatodactyl like a finger united at the basis of the movable cheliceral digit, chaetotaxy of legs: genu III $(2,4 / 1,1)$, genu IV $(2,5 / 1,1)$.

The genus was revised by Karg (1976, 1993b). Diagnoses of 16 species were provided, and eleven species described as new. In the following section of our investigation we describe two new species and arrange the differential diagnoses as a key for the new and known species.

\section{Gamasiphoides acanthioides n. sp.}

Holotype - o Brazil 1970, Bom Jesus de Pirapora, humus, collector K. Lenko.

Paratypes -1 o, 1 o", 2 deuto-nymphs, the same habitat.

Etymology - Acanthion = porcupine, as to the long setae of the body.

Diagnosis - Characterized by remarkable long setae of the dorsum, a broad and pointed tectum, a ventrianal shield distinctly wider than long and very slender metapodal shields behind coxae IV (Figures 11, 12). 
Karg W. and Schorlemmer A.

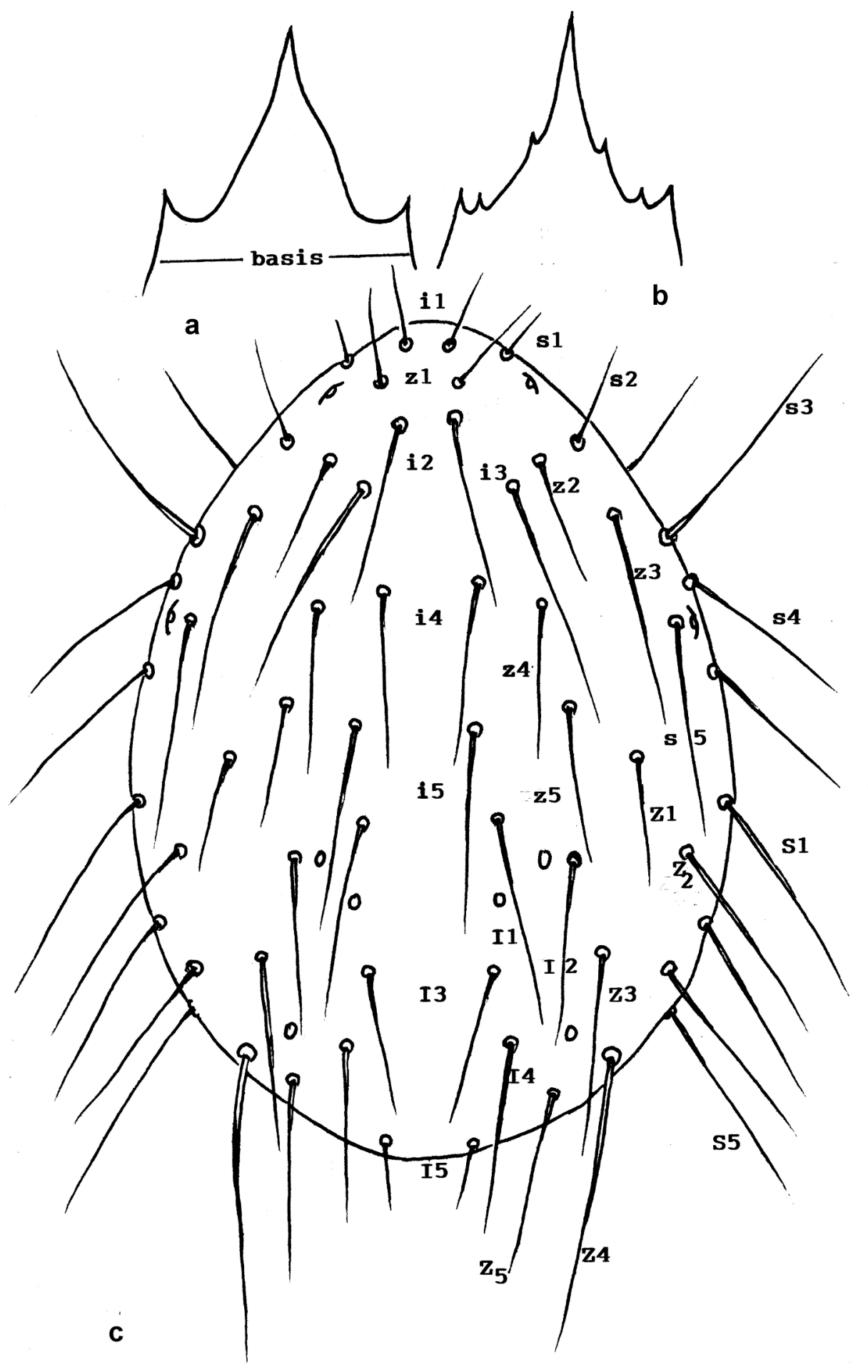

FIGURE 11: Gamasiphoides acanthioides n. sp. a - Female Tectum, $42 \mu \mathrm{m}$ wide; b - Deuto-nymph Tectum, $35 \mu \mathrm{m}$ wide; $\mathrm{c}$ - Female Dorsum, 660-670 $\mu \mathrm{m}$ long. 


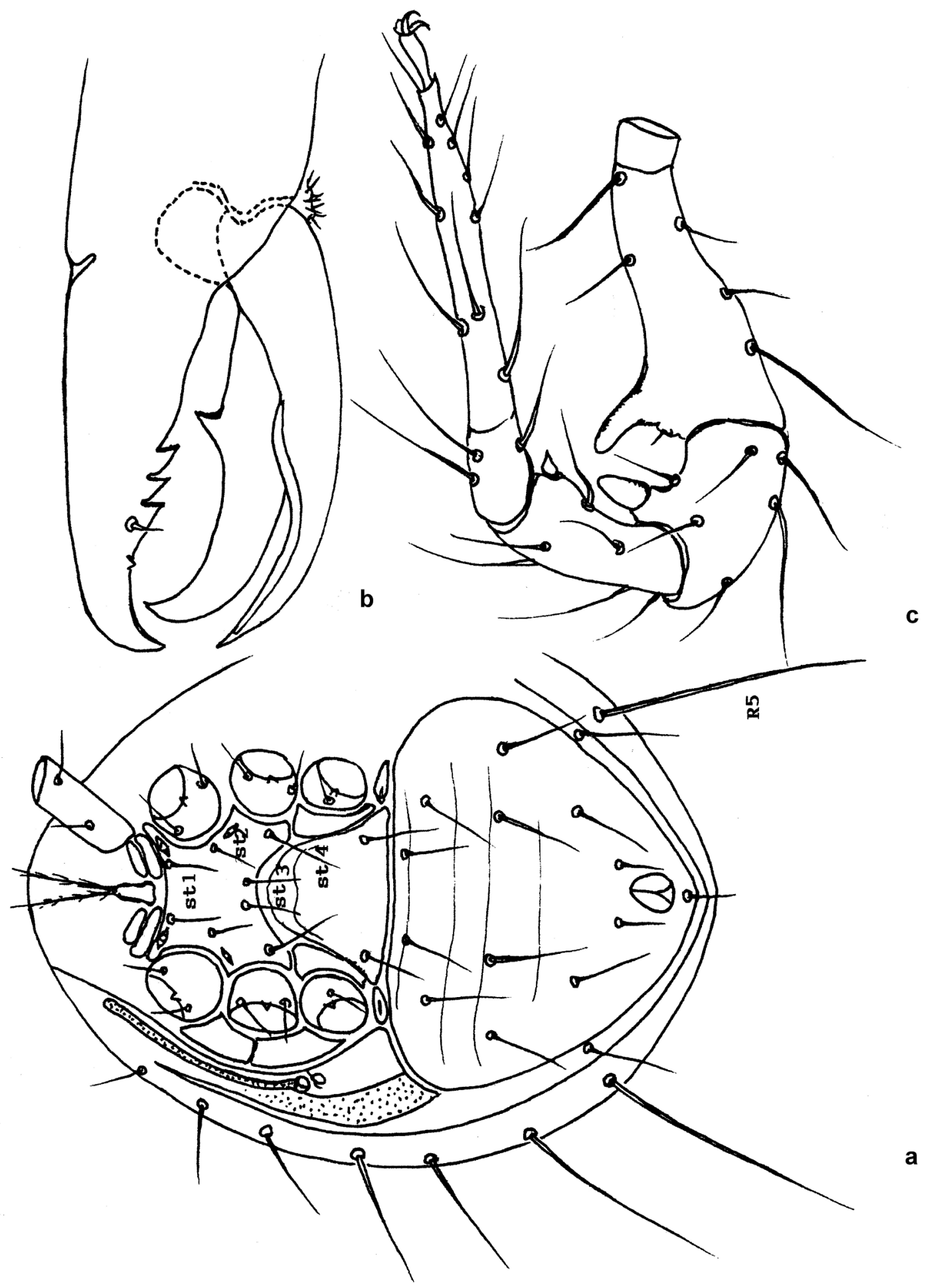

FIGURE 12: Gamasiphoides acanthioides n. sp. a - Female Venter; b - Male Chelicera, $10 \mu \mathrm{m}$; c - Male Femur, genu, tibia, tarsus of leg II, $52 \mu \mathrm{m}$ long. 
Karg W. and Schorlemmer A.

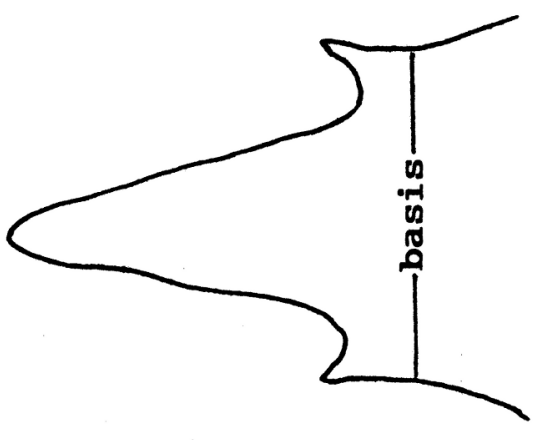

C

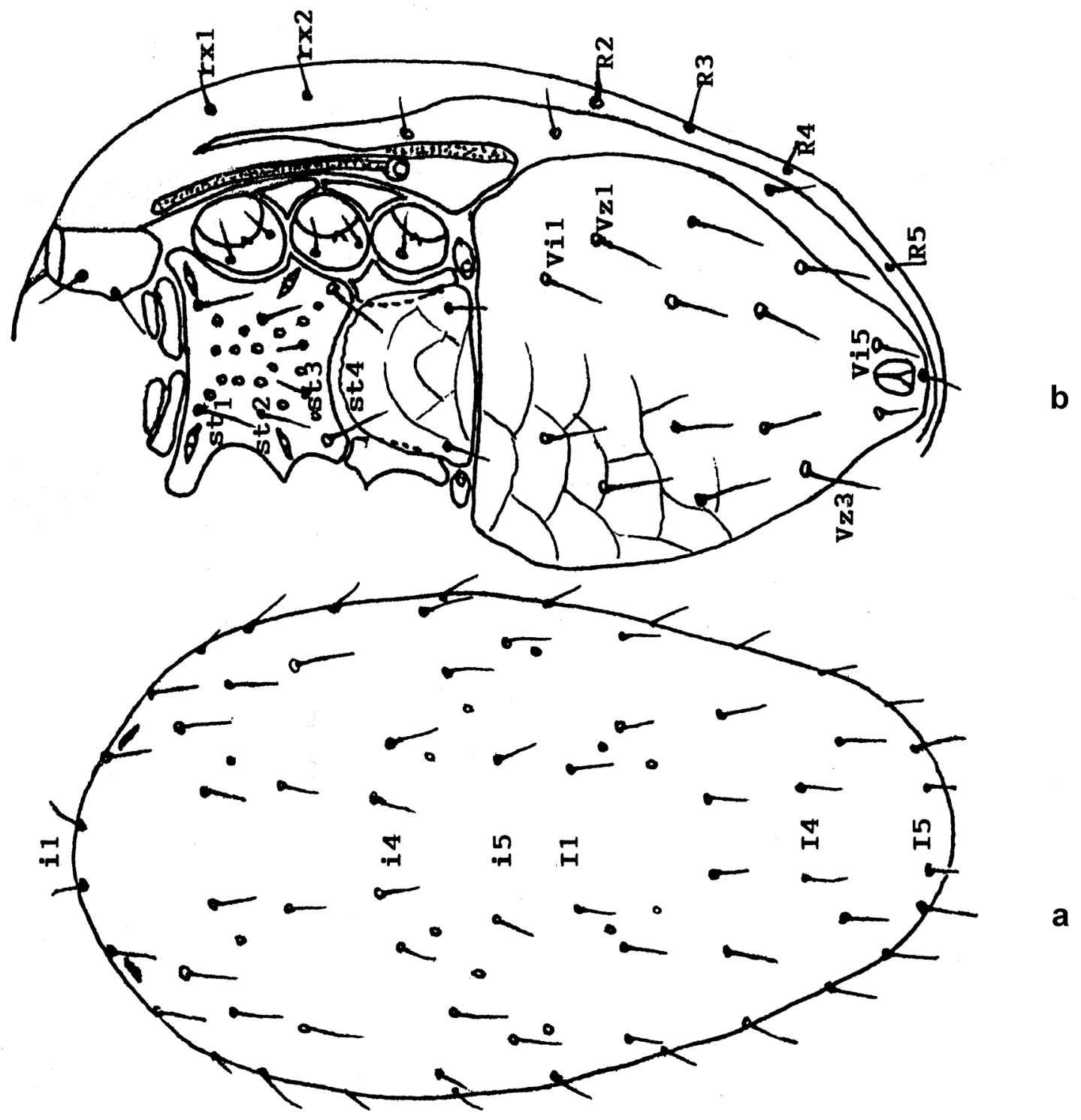

FIGURE 13: Gamasiphoides procerus n. sp. Female. a - Dorsum, $635 \mu \mathrm{m}$ long; b - Venter; c - Tectum, $74 \mu \mathrm{m}$ wide. 


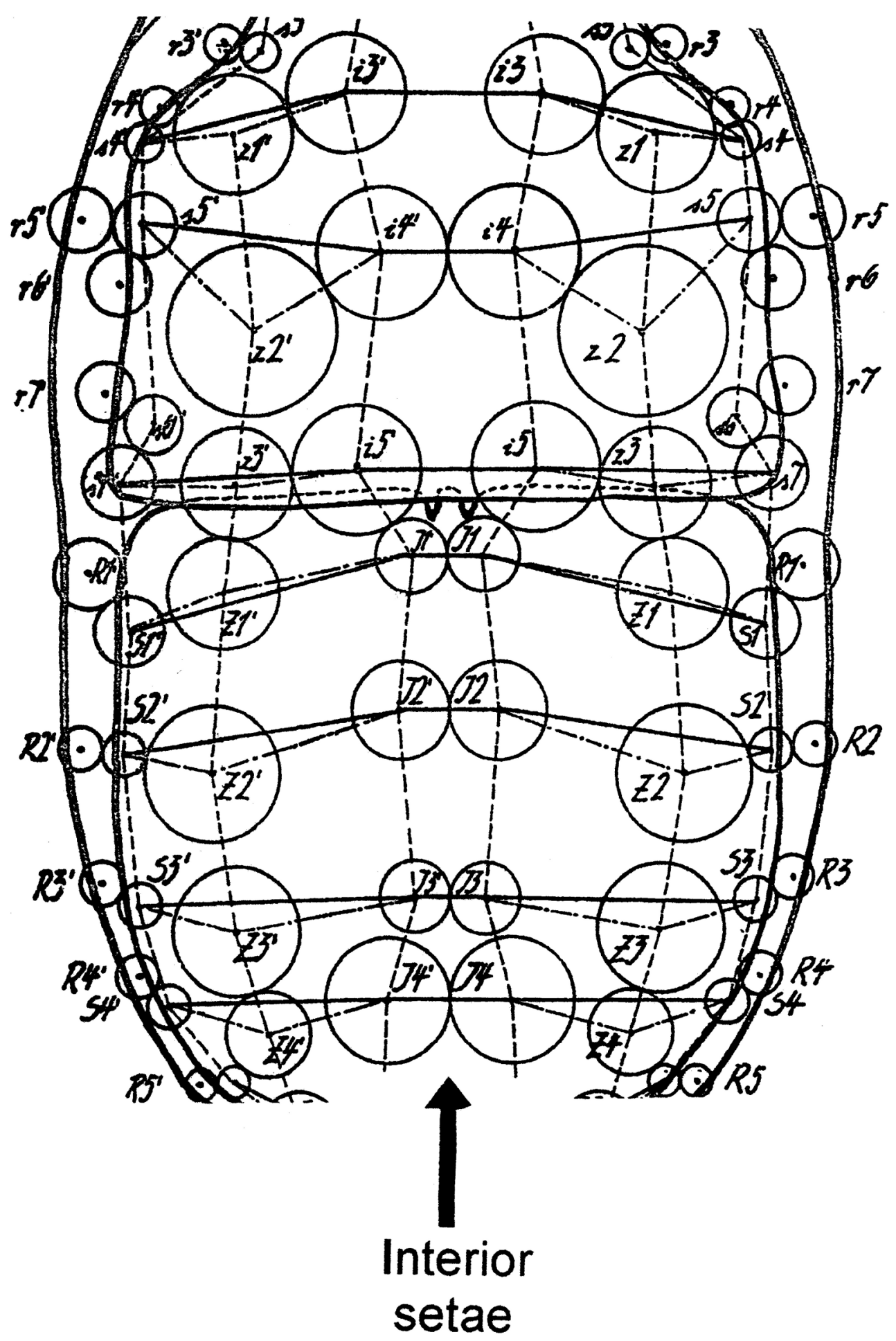

FIGURE 14: Cropping of a figure taken from the fundamental publication of Werner Hirschmann (1957): Gangsystematik der Parasitiformes, Teil1: Rumpfbehaarung und Rückenfflächen. He distinguished four pairs of longitudinal rows of setae: $r, R=R a n d-, s, S=$ Seiten-, z, Z = Zwischen- and i, I = Innenhaare (Interior setae). Werner Hirschmann added the letters in German hand writing into his figures. 
Description - Idiosoma $9660-670 \times 445-487$ $\mu \mathrm{m}$, brown.

Dorsum: With remarkable long setae, especially lateral and posterior setae long, caudal setae Z4 as long as half the width of the dorsum, setae at the vertex shorter, $\mathrm{i} 1=53, \mathrm{~s} 1=24, \mathrm{z} 2=70, \mathrm{z} 3=140, \mathrm{i} 2=$ $88, \mathrm{i} 3=140, \mathrm{i} 4=90, \mathrm{i} 5=105, \mathrm{~s} 2=63, \mathrm{~s} 3=175, \mathrm{~s} 4=$ $140, \mathrm{I} 1=90, \mathrm{I} 2=105, \mathrm{I} 3=77, \mathrm{I} 4=105, \mathrm{I} 5=35, \mathrm{Z} 3=$ $105, \mathrm{Z} 4=235, \mathrm{~S} 1=140, \mathrm{~S} 5=182 \mu \mathrm{m}$ long.

Venter: Marginal-caudal part of the dorsum turned down to the venter carrying the $\mathrm{r}$ - and $\mathrm{R}$ setae, posterior setae of them longer than the anterior setae, $\mathrm{R} 5=210 \mu \mathrm{m}$ long, peritrematal shields with a dotted marginal strip, sternal setae st1, st2, st3 35 to $40 \mu \mathrm{m}$ however st $4=60 \mu \mathrm{m}$ long, genital setae $70 \mu \mathrm{m}$, ventrianal shield with six pairs of setae (including paranal setae), 60 to $70 \mu \mathrm{m}$ long, ventrianal shield $350 \mu \mathrm{m}$ wide and $280 \mu \mathrm{m}$ long, on body-shields no distinct structure-lines visible, only on the ventrianal shield some fine transverse lines, the small metapodal shields behind coxae IV like slender double-sided wedges.

Gnathosoma: Middle point of the tectum relative broad, shorter $(=28 \mu \mathrm{m})$ than the width of the tectum-basis $(=42 \mu \mathrm{m})$, hypostomatic setae $\mathrm{C} 2$ and $\mathrm{C} 3$ inserted at the same level, $\mathrm{C} 1=50, \mathrm{C} 2=68, \mathrm{C} 3=$ $77, \mathrm{C} 4=70 \mu \mathrm{m}$ long.

Legs: $\mathrm{I}=740, \mathrm{II}=652, \mathrm{III}=610, \mathrm{IV}=696 \mu \mathrm{m}$ long, relevant chaetotaxy on genu III $=2,4 / 1,1$ and genu $\mathrm{IV}=2,5 / 1,1$ corresponding with the known patterns of the genus.

Idiosoma o" $609 \times 348 \mu \mathrm{m}$, setation of shields and shape of the tectum similar to the females, however, legs I longer than the idiosoma: $=740 \mu \mathrm{m}$ long, legs II with spurs at femur, genu and tibia, movable digitus of chelicerae with pointed spermatodactyl as long as the digitus.

Idiosoma deuto-nymph $522 \times 418 \mu \mathrm{m}$, setation similar in female and male, tectum with small additional points.

\section{Gamasiphoides procerus n. sp.}

Holotype — o Paraguay 1966, Puerto Presidente Stroessner, litter and soil from liana-shrubbery, $50 \mathrm{~m}$ above Acaray waterfall, collector I. Loksa.
Etymology - Procerus $=$ slender, as to the remarkable body shape of the species.

Diagnosis - Remarkable slender shape of the idiosoma, short setae of dorsum, ventrianal shield distinctly longer than wide, marginal stripe of the dorsum turned down to the venter carrying the marginal $\mathrm{r}$ - and R-setae (Figure 13).

Description - Idiosoma $q 635 \times 383 \mu \mathrm{m}$, brown.

Dorsum: With short setae, most 17 to $20 \mu \mathrm{m}$ long, caudal setae $\mathrm{I} 5$ very short: $=8 \mu \mathrm{m}$ long.

Venter: Marginal stripes of the dorsum turned down to the venter carrying $2 \mathrm{r}$-setae and $4 \mathrm{R}$-setae, sternal shield with a pore-like pattern, sternal setae of different length: $\mathrm{st} 1=25$, st $2=20$, st $3=17$, st $4=$ $30 \mu \mathrm{m}$ long, genital and ventrianal shields with netlike patterns, most setae on the ventrianal shield 20 to $25 \mu \mathrm{m}$ long however Vi5 $=15$ and Vz3 $=35 \mu \mathrm{m}$ long, the small metapodal shields behind coxae IV oval with a glandular pore at the inner end, posterior part of peritrematal shields broadened and in contact with the ventrianal shield, with a slender dotted lateral margin.

Gnathosoma: Tectum with a strong middle branch, $320 \mu \mathrm{m}$ long, distinctly longer than the width of the tectum-basis $(290 \mu \mathrm{m})$.

Legs: I $=480, \mathrm{II}=392, \mathrm{III}=348, \mathrm{IV}=470 \mu \mathrm{m}$ long, relevant chaetotaxy on genu III $=2,4 / 1,1$ and genu IV $=2,5 / 1,1$ corresponding with the known patterns of the genus Gamasiphoides.

\section{KEY TO SPECIES OF Gamasiphoides WOMERSLEY, 1956 BASED ON $q$}

We always compare the characteristics of a number with the contrasting features of the number that is given in parentheses. For example, 1 (20) compares number 1 to number 20 . If number 1 applies we move on to number 2. 2 (5) then compares number 2 to number 5 . If number 2 applies we move on to number 3. But if number 5 applies we move on to number 6 , etc. In this way, related species remain together and the overview of relationships is conserved. 
1 (20) Ventrianal shield not fused with the dorsum.

2 (5) Ventrianal shield distinctly broader than long.

3 (4) Dorsal setae short, i4 = 1/5 distance i4-i5, I1 = $1 / 2$ distance I1-I2, idiosoma $760 \mu \mathrm{m}$ long

\section{G. macquariensis Hirschmann, 1966 - Macquary-island}

4 (3) Dorsal setae long, i4 = longer than distance i4i5, I1 = longer than three times the distance I1-I2, idiosoma 660-670 $\mu \mathrm{m}$ long

\section{G. acanthioides n. sp. - Brazil}

5 (2) Ventrianal shield as broad as long or longer than broad.

6 (13) Ventrianal shield nearly as broad as long.

7 (8) Dorsal setae very long, posterior I-setae longer than distances to the next setae of the series, idiosoma 710-750 $\mu \mathrm{m}$ long

G. longosetis Karg, 1976-Chile

8 (7) Setae of the dorsum short, shorter than distances to the next setae in series.

9 (10) Middle branch of the tectum three times as long as the width of the tectum-basis (behind the pair of lateral points), idiosoma 630-650 $\mu \mathrm{m}$ long

\section{G. longocuspis Karg, 1976 - Chile}

10 (9) Middle branch of the tectum only a little longer than the tectum-basis or shorter.

11 (12) Ventrianal shield with eight pairs of setae, shape of the small metapodal shields behind coxae IV oval to circular, middle branch of the tectum variable, idiosoma 680-800 $\mu \mathrm{m}$ long

$$
\text { G. octosetae Karg, } 1976 \text { - Chile }
$$

12 (11) Ventrianal shield with seven pairs of setae, shape of the small metapodal shields behind coxae IV like a grip, middle branch of the tectum a little longer than the tectum-basis, idiosoma 410-440 $\mu \mathrm{m}$ long

G. brevisetis Karg, 1976 - Chile
13 (6) Ventrianal shield distinctly longer than broad. 14 (19) Shape of the small metapodal shields behind coxae IV oval to triangular, sternal setae st3 localized behind sternal setae st2.

15 (18) Setae of the dorsum short, $\mathrm{i} 4=1 / 4$ to $1 / 2$ distance $\mathrm{i} 4-\mathrm{i} 5, \mathrm{I} 1$ = distance I1-I2 or 1/2 distance I1-I2, posterior part of the peritrematal shields well developed, as broad as coxae IV.

16 (17) Setae of the dorsum very short, i4 = 1/4 distance i4-i5, I1 = 1/2 distance I1-I2, middle branch of the tectum strong and longer than the tectum-basis, setae of sternal shield of different length: st3 $=17$, st $4=30 \mu \mathrm{m}$ long, idiosoma $635 \mu \mathrm{m}$ long

$$
\text { G. procerus n. sp. - Paraguay }
$$

17 (16) Setae of the dorsum not so greatly shortened, i4 = 1/2 distance i4-i5, I1 = distance I1-I2, setae of sternal shield of nearly equal length however st1, st 2 and st 3 thorn-like, idiosoma 570-610 $\mu \mathrm{m}$ long

$$
\text { G. longoventris Karg, } 1976 \text { - Chile }
$$

18 (15) Setae of the dorsum of middle length, i4 as long as distance i4-i5, I1 longer than distance I1-I2, posterior part of the peritrematal shields weak developed, only half as broad as coxae IV, idiosoma $420 \mu \mathrm{m}$ long

$$
\text { G. aitkeni Lee, } 1970 \text { - Australia }
$$

19 (14) Shape of the small metapodal shields behind coae IV like a grip, sternal setae st3 and st2 localized in a transverse line, middle branch of the tectum longer than the tectum-basis, surface of all bodyshields with distinct net-like patterns, idiosoma 650 $\mu \mathrm{m}$ long

\section{G. linealis Karg, 1976 - Chile}

20 (1) Ventrianal shield caudal fused with the dorsum.

21 (24) Ventrianal shield distinctly longer than broad.

22 (23) Ventrianal shield with seven pairs of setae, setaeVz1 localized behind Vi1, sternal setae-pair st1 localized together more narrow than st3, idiosoma 665 $\mu \mathrm{m}$ long

G. gamasiphoides Sheals, 1962 - Argentina, Brasil 
23 (22) Ventrianal shield with eight pairs of setae, setaeVz1 localized beside Vi1, sternal setae-pair st3 localized together more narrow than st1, idiosoma 520-560 $\mu \mathrm{m}$ long

\section{G. coniunctus Karg, 1976 - Chile}

24 (21) Ventrianal shield as broad as long or broader than long.

25 (26) Ventrianal shield broader than long and with eight pairs of setae, posterior part of the peritrematal shields remarkably broadened, twice as broad as coxae IV and with one seta at the posterior margin, setae on the anterior part of the dorsum distinctly longer $(90-100 \mu \mathrm{m})$ than on the posterior part (55-70 $\mu \mathrm{m})$, idiosoma, $800 \mu \mathrm{m}$ long

G. setosus Karg, 1976 - Chile

26 (25) Ventrianal shield nearly as broad as long, posterior part of the peritrematal shields about as broad as coxae IV and without a seta at the posterior margin.

27 (28) Marginal setae remarkably long, length = $1 / 6$ the length of the idiosoma, the caudal setae Z5 not longer, ventrianal shield with 9 pairs of setae, idiosoma $630 \mu \mathrm{m}$ long

G. costai Lee et Hunter, 1974 - New Zealand

28 (27) Marginal setae and setae of the middle region of the dorsum nearly equal in length, 1/16 to $1 / 10$ as long as the idiosoma, 25 to $70 \mu \mathrm{m}$ long, however caudal setae $\mathrm{Z} 5$ in some species longer.

29 (32) Sternal setae-pair st1-st1 localized together just as narrow as setae-pair st3-st3.

30 (31) Posterior part of the peritrematal shields very slender, $1 / 2$ the width of coxae IV, dorsal setae remarkably short, 25 to $30 \mu \mathrm{m}$ long, lateral branches of the tectum reduced to two pairs of tiny points, $1 / 20$ the length of the middle branch, idiosoma 550 $\mu \mathrm{m}$ long

\section{G. leptogenitalis Karg, 1993 - New-Caledonia}

31 (30) Posterior part of the peritrematal shields remarkable broadened, as broad as coxae IV, setae st3 of sternal shield thorn-like, most of dorsal setae 55 to $65 \mu \mathrm{m}$ long, only Z5 1.5 times as long as other setae, idiosoma 650-720 $\mu \mathrm{m}$ long

$$
\text { G. baloghi Karg, } 1976 \text { - Chile }
$$

32 (29) Distance of sternal setae st1-st1 distinctly longer than of setae st3-st3, caudal setae Z5 distinctly longer than other dorsal setae.

33 (34) Posterior part of the peritrematal shields remarkably broadened, as broad as coxae IV, one pair of lateral branches of the tectum with $1 / 4$ the length of the middle branch, idiosoma $780 \mu \mathrm{m}$ long

$$
\text { G. propinqua Womersley, } 1956 \text { - Australia }
$$

34 (33) Posterior part of the peritrematal shields very slender $=1 / 2$ the width of coxae IV, 4 to 5 pairs of lateral branches of the tectum with only $1 / 20$ the length of the middle branch, post anal seta in relation to all other species remarkably long, $=60 \mu \mathrm{m}$ long, other setae of the ventrianal shield 32-35 $\mu \mathrm{m}$ long, idiosoma 660-690 $\mu \mathrm{m}$ long

G. postanalis Karg, 1993 - New-Caledonia

\section{ACKNOWLEDGMENTS}

We are indebted to Prof. Dr. A. Zicsi, University of Budapest and Prof. Dr. Mahunca, Hungarian Natural Hist. Museum, Budapest, for sending us mites sampled in South America, to Prof. Dr. G. O. Evans, Great Britain who inspired comparisons concerning chaetotaxy of legs.

\section{REFERENCES}

Alberti G. 1995 - Comparative Spermatology of Chelicerata: Review and Perspective. In: Jamieson B. G. M, Ausio J., Justine J. L. (Eds). Advances in Spermatozoal Phylogeny and Taxonomy. - Mémoires du Muséum national d'Histoire naturelle, 166: 203-230.

Alberti G., 2000a — Spermatologische Untersuchungen an Gamasiden - Abhandlungen und Berichte des Naturkundemuseums Görlitz, 72(1): 91-96.

Alberti G. 2000b - Chelicerata - In: Jamieson, B. G. M. (Eds). Progress in Male Gamete Ultrastructure and Phylogeny, in: Adiyodi, K.G., Adiyodi, R. G. (Eds). Biology of the Invertibrates, Vol. 9, p.B. Oxford \& JBH Publishing Co. PVT. LTD.:311-388. 
Baker E. W., Camin J. H., Cunliffe F., Woolley T. A, Yunker C. E., 1958 - Guide to the families of Mites - Contribution number 3 of The Institute of Acarology, Department of Zoology, University of Maryland, College Park, pp. 230. Berker J. 1956 - 1. Über die Bedeutung der Raubmilben innerhalb der Spinnmilbenbiozönose auf Apfel 2. über den Einfluß zweier Raubmilben auf den Populationsverlauf von Metatetranychus ulmi Koch - Mitteilungen der Biologischen. Bundesanstalt für Land- u. Forstwirtschaft, Berlin-Dahlem 85: 44-48.

Begljarov G. A. 1967 - Ergebnisse der Untersuchungen und der Anwendung von Phytoseiulus persimilis Athias-Henriot 1957 als biologisches Bekämpfungsmittel gegen Spinnmilben in der Sowjetunion Nachrichtenblatt für den Deutschen Pflanzenschutzdienst, Berlin NF 21: 197-200.

Camin J. H., Gorirossi F. 1955 - A revision of the suborder Mesostigmata, Acarina, based on new interpretations of comparative morphological data - The Chicago Academy of Sciences Special Publication 11: 1-70.

Canestrini G. 1891 - Abbozzo del sistema acarologico - Atti del Reale Instituto Veneto di Scienze, Lettre et Arti, ser. 7. t. II: 699 -725.

Christian A., Karg W. 2008 - A revised setal nomenclature based on ontogenetic and phylogenetic characters and universally applicable to the idiosoma of Gamasina (Acarina, Parasitiformes) - Soil Organisms, Görlitz, 80(1): 45-79.

Dosse G. 1956 - Über die Entwicklung einiger Raubmilben bei verschiedenen Nahrungstieren Acar., Phytoseiidae - Pflanzenschutzberichte 16: 122-136.

Dowling A. P. G., OConnor B. M. 2010 - Phylogeny of Dermanyssoidea (Acari: Parasitiformes) suggests multiple origins of parasitism - Acarologia 50(1): 113-129. doi:10.1051/acarologia/20101957

Edwards A. M., Evans G. O. 1967 - Some observations on the chaetotaxy of the legs of larval Ixodidae (Acari: Metastigmata) - Journal of Natural History, 4: 595601. doi:10.1080/00222936700770561

Evans G. O. 1963 - Observations on the Chaetotaxy of the legs in the free-living Gamasina (Acari Mesostigmata) - Bulletin of the British Museum Natural History, Zoology, London, 10(5): 277-303.

Evans G. O., Till W. M. 1979 - Mesostigmatic mites of Britain and Ireland (Chelicerata: AcariParasitiformes), an introduction to their external morphology and classification - Transactions of The Zoological Society of London, 35: 139-270.

Hennig R. 1950 - Grundzüge einer Theorie der Phylogenetischen Systematik. Berlin, pp. 370.

Hennig R. 1966 - Phylogenetic systematics - University of Illinois Press, Urbana, Chicago, London, pp. 263.
Hennig R. 1994 - Allgemeine Vorbemerkungen zum System der Tiere - In: Taschenbuch der Speziellen Zoologie, Wirbellose I, Gustav Fischer Verlag Jena, pp. 392.

Hirschmann W. 1957 - Gangsystematik der Parasitiformes, Teil 1: Rumpfbehaarung und Rückenflächen - Acarologie, Schriftenreihe für Vergleichende Milbenkunde, 1. Folge, Teil 1, pp.20.

Hirschmann W., Zirngiebl-Nicol I. 1961 - Die Gattung Trichouropoda Berlese, 1916, die Cheliceren und das System der Uropodiden - Acarologie, Schriftenreihe für Vergleichende Milbenkunde, 4. Folge, Teil 4, pp.41.

Hunter P. E., Costa, M. 1970 - Two new African Species of Megisthanus Thorell Mesostigmata: Megisthanidae — Florida Entomologist 53(4): 233240. doi:10.2307/3493194

Karg W. 1961 - Ökologische Untersuchungen von edaphischen Gamasiden (Acarina Parasitiformes), 1. und 2. Teil - Pedobiologia 1(1): 53-74 and (2): 77-98.

Karg W. 1962 - Zur Systematik und postembryionalen Entwicklung der Gamasiden (Acarina, Parasitiformes) landwirtschaftlich genutzter Böden - Mitteilungen aus dem Zoologischen Museum in Berlin, 38: 23-119.

Karg W. 1965 - Larvalsystematische und phylogenetische Untersuchung sowie Revision des Systems der Gamasina Leach, 1915 (Acarina, Parasitiformes) - Mitteilungen aus dem Zoologischen Museum in Berlin, 41(2): 193-340. doi:10.1002/mmnz.19650410207

Karg W. 1972 - Untersuchungen über die Korrelation zwischen dominierenden Raubmilbenarten und ihrer möglichen Beute in Apfelanlagen - Archiv für Pflanzenschutz, Berlin 8(1): 29-52.

Karg W. 1976 - Zur Kenntnis der Milbengattungen Gamasiphoides Womersley, 1956 und Laelaptiella, Womersley, 1956 (Acarina, Parasitiformes) - Mitteilungen aus dem Zoologischen Museum in Berlin, 52(1): 3-24. doi:10.1002/mmnz.19760520102

Karg W. 1982 - Untersuchungen über Habitatansprüche, geographische Verbreitung und Entstehung von Raubmilbengattungen der Cohors Gamasina für ihre Nutzung als Bioindikatoren - Pedobiologia 24: 241247.

Karg W. 1986 - Systematische Untersuchung der mitteleuropäischen Uropodina Kramer, 1881 Acarina, Parasitiformes - Zoologische Jahrbücher, Jena 113: 79-96.

Karg W. 1989 - Acari (Acarina), Milben, Unterordnung Parasitiformes, Uropodina Kramer, Schildkrötenmilben - In: Die Tierwelt Deutschlands 67. Teil, Gustav Fischer Verlag Jena, pp. 203.

Karg W. 1991 - The Integration of morphologic, biogeographic and palaeogeographic Studies to reveal the Phylogeny of predatory Mites - In: Dusbabek, F., V. 
Bukva (Eds).: Modern Acarology. Academia, Prague, SPB Academic Publishing bv, The Hague, The Netherlands, 2: 121-127.

Karg W. 1993a - Acari (Acarina), Milben, Parasitiformes (Anactinochaeta) Cohors Gamasina Leach: Raubmilben - Tierwelt Deutschlands, 59. Teil. Gustav Fischer Verlag. Jena, Stuttgart, New York, pp. 523.

Karg, W. 1993b - Neue Raubmilben der Rhodacaridae Oudemans (Acarina, Parasitiformes) aus NeuKaledonien - Zoologische Jahrbücher, Systematik, 120: 39-63.

Karg W. 1994a — Raubmilben, nützliche Regulatoren im Naturhaushalt - Die neue Brehm- Bücherei, Band 624, Westarp Wissenschaften, Magdeburg, pp. 206.

Karg W. 1994b - Raubmilben der Cohors Gamasina Leach (Acarina Parasitiformes) vom GalapagosArchipel - Mitteilungen aus dem Zoologischen $\mathrm{Mu}-$ seum in Berlin, 70: 179-216.

Karg W. 1996 - Neue Arten aus Raubmilbengattungen der Gamasina Leach (Acarina, Parasitiformes) mit Indikationen zum Entwicklungsalter - Miteilungen aus dem Zoologischen Museum in Berlin, 721: 149-195.

Karg W. 1997a - Neue Raubmilbenarten der Antennophoridae Berlese, 1892 (Acarina, Parasitiformes), phoretisch auf Passaliden - Mitteilungen aus dem Zoologischem Museum in Berlin, 73(1): 51-61.

Karg W. 1997b — Die Raubmilbenfamilie Leptolaelapidae Karg (Acarina, Parasitiformes) - Acarologia, 38(3): 207-218.

Karg W. 1998 - Zur Kenntnis der Eugamasides Karg mit neuen Arten aus den Regenwäldern von Ecuador (Acarina, Parasitiformes) - Mitteilungen aus dem Museum für Naturkunde in Berlin, Zoologische Reihe, 742: 185-214.

Karg W. 2000a - Zur Systematik der Raubmilbenfamilien Hypoaspididae v. Vitzthum, 1941 und Rhodacaridae Oudemans, 1902 (Acarina, Parasitiformes) mit neuen Arten aus Süd- und Mittelamerika - Mitteilungen aus dem Museum für Naturkunde in Berlin, Zoologische Reihe, 76(2): 243-262. doi:10.1002/mmnz.20000760207

Karg W. 2000b - Neue Raubmilbenarten der Pionierartengruppe Rhodacaridae Oudemans (Acarina, Parasitiformes) - Abhandlungen und Berichte des Naturkundemuseums Görlitz, 72(2): 207-213.

Karg W. 2003a - Die Raubmilbengattungen Afrogamasellus Loots et Ryke und Oloopticus Karg mit zwei neuen Arten - Ein Beitrag zur Evolution der Bodenmilben (Acarina, Gamasina) - Abhandlungen und Berichte des Naturkundemuseums Görlitz, 75(1): 1323.

Karg W. 2003b - Neue Raubmilbenarten aus dem tropischen Regenwald von Ecuador mit einem kritischen
Beitrag zur Merkmalsevolution bei Gamasina (Acarina, Parasitiformes) - Mitteilungen aus dem $\mathrm{Mu}-$ seum für Naturkunde in Berlin, Zoologische Reihe, 78: 229-251.

Karg W. 2006 - The systematics of Parasitiformes, especially of Gamasina Leach (Acarina), with new species from Ecuador - Mitteilungen aus dem Museum für Naturkunde in Berlin, Zoologische Reihe, 82(1): 140169. doi:10.1002/mmnz.200600002

Karg W. 2007 - New taxonomic knowledge of soilinhabiting predatory mites (Acarina, Gamasina: Rhodacaroidea, Dermanyssoidea, Ascoidea) - Abhandlungen und Berichte des Naturkundemuseums Görlitz 78(2): 113-139.

Karg W., Freier B. 1995 - Parasitiforme Raubmilben als Indikatoren für den Zustand von Ökosystemen Mitteilungen aus der Biologischen Bundesanstalt für Land- und Forstwirtschaft, Berlin-Dahlem, Heft 308, pp. 96.

Karg W., Schorlemmer A. 2008 - Origin and classification of the Ixodides (Ticks) within the Parasitiformes Reuter 1909 Acarina - Acarologia, 48: 123-134.

Karg W., Schorlemmer A. 2009 - New insights into predatory mites (Acarina, Gamasina) from tropical rain forests with special reference to distribution and taxonomy - Zoosystematic and Evolution, 85(1): 5791.

Klompen H. 2000 - A priliminary assesment of the utility of elongation factor $-1 a$ in elucidating relationships among basal Mesostigmata - Experimental and Applied Acarology, 24: 805-820. doi:10.1023/A:1006432017638

Krantz G. W., Ainscough B. D. 1990 - Acarina: Mesostigmata (Gamasida) - Soil Biology Guide. Edited by Daniel L. Dindal: 583-665.

Krantz G. W., Walter D. E. (Eds.) 2009 - A manual of Acarology 3rd Edition - Texas Tech University Press, pp. 807.

Lindquist E. E., Moraza M. L. 1993 - Pyrosejidae, a new family of Trigynaspid Mites (Acari: Mesostigmata: Cercomegistina) from Middle America - Acarologia, 34(4): 283-307.

Moraza, M. L. 2004 - Tarsus I chaetotaxy and structure in Anactinotrichida mites: characters with phylogenetic value - Phytophaga, 14: 347-359.

Lehtinen P. T. 1991 - Phylogeny and zoogeography of the Holothyrida — In: Dusbabek and Bukva, 2: 101113.

Walter D. E., Krantz G. W. 1999 - New early derivate Mesostigmatans from Australia: Nothogynus n.g., Nothogynidae n. fam. (Mesostigmata: Microgyniina) - International Journal of Acarology, 25(2): 67-76. doi:10.1080/01647959908683618 
Walter D. E., Proctor H. C. 1999 - Mites: Ecology, Evolution and Behaviour - Sydney: University of NSW Press, pp. 322.

\section{COPYRIGHT}

$(\mathrm{cc})$ EY-No-ND Karg and Schorlemmer. Acarologia is under free license. This open-access article is distributed under the terms of the Creative Commons-BY-NC-ND which permits unrestricted non-commercial use, distribution, and reproduction in any medium, provided the original author and source are credited. 